This document was prepared in conjunction with work accomplished under Contract No. DE-AC09-96SR18500 with the U. S. Department of Energy.

\title{
DISCLAIMER
}

This report was prepared as an account of work sponsored by an agency of the United States Government. Neither the United States Government nor any agency thereof, nor any of their employees, makes any warranty, express or implied, or assumes any legal liability or responsibility for the accuracy, completeness, or usefulness of any information, apparatus, product or process disclosed, or represents that its use would not infringe privately owned rights. Reference herein to any specific commercial product, process or service by trade name, trademark, manufacturer, or otherwise does not necessarily constitute or imply its endorsement, recommendation, or favoring by the United States Government or any agency thereof. The views and opinions of authors expressed herein do not necessarily state or reflect those of the United States Government or any agency thereof.

This report has been reproduced directly from the best available copy.

Available for sale to the public, in paper, from: U.S. Department of Commerce, National Technical Information Service, 5285 Port Royal Road, Springfield, VA 22161, phone: (800) 553-6847, fax: (703) 605-6900

email: orders@ntis.fedworld.gov

online ordering: http://www.ntis.gov/help/index.asp

Available electronically at http://www.osti.gov/bridge

Available for a processing fee to U.S. Department of Energy and its contractors, in paper, from: U.S. Department of Energy, Office of Scientific and Technical Information, P.O. Box 62, Oak Ridge, TN 37831-0062,

phone: (865)576-8401,

fax: (865)576-5728

email: $\underline{\text { reports@ adonis.osti.gov }}$ 
WSRC-TR-2000-00411

SRT-RPP-2000-00027

BNF-003-98-0251

KEYWORDS:

Hanford River Protection Project

Cesium Ion Exchange

SuperLig 644

Nitric Acid

Stability

\section{SuperLig $^{\mathrm{TM}} 644$ Ion Exchange Resin Stability in Nitric Acid at Elevated Temperatures}

SAVANNAH RIVER TECHNOLOGY CENTER

H. H. Saito, 773-42A

W. J. Crooks, III, 773-A

D. J. McCabe, 773-42A

C. A. Nash, 773-42A

Publication Date: April 2001

Westinghouse Savannah River Company

Savannah River Site

Aiken, SC 29808

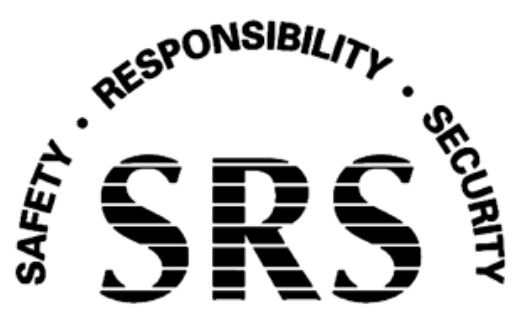

Prepared for the U.S. Department of Energy under Contract No. DE-AC09-96SR18500 
DOCUMENT: WSRC-TR-2000-00411 (SRT-RPP-2000-00027, formerly BNF-003-98-025 I)

TITLE: SuperLig 644 lon Exchange Resin Stability in Nitric Acid at Elevated Temperatures

APPROVALS

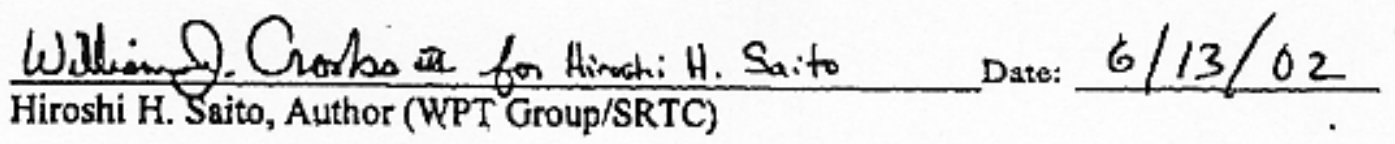

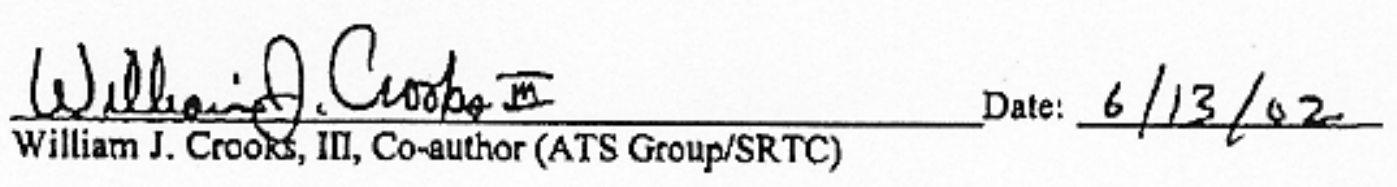

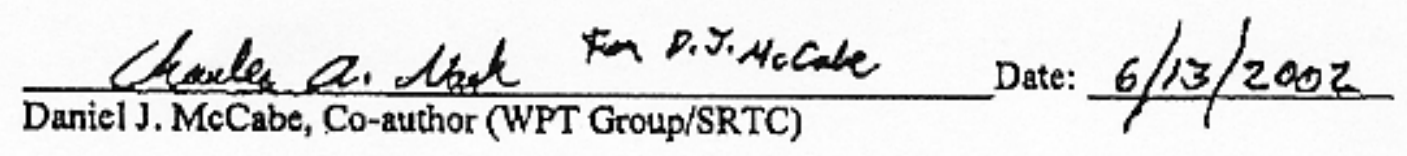

$\frac{\text { Char las le Nosh Date: } 6 / 13 / 200 Z}{\text { Charles A. Nash, Coauthor (WPT Group/SRTC) }}$
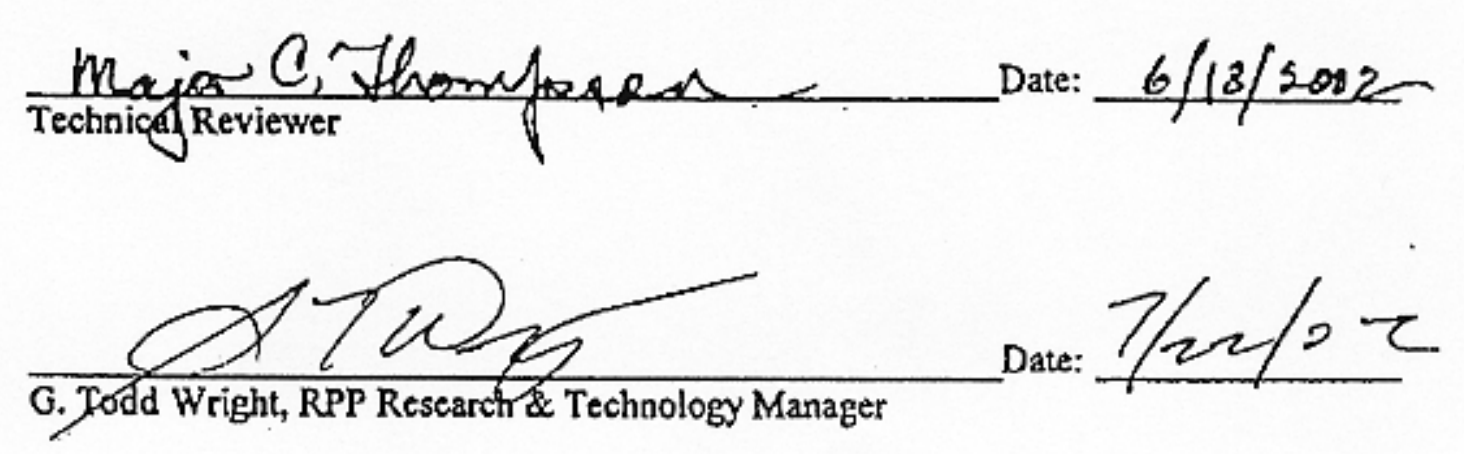


\section{Contents}

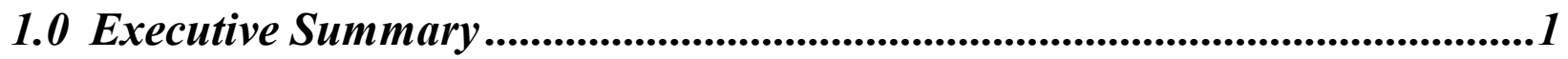

2.0 Introduction and Background...........................................................................1

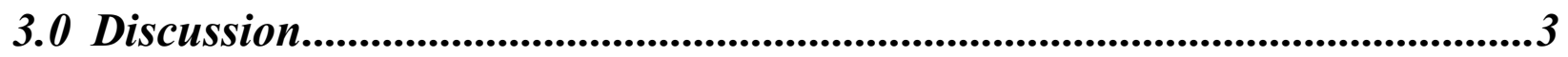

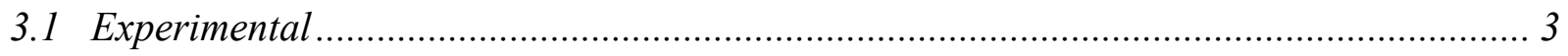

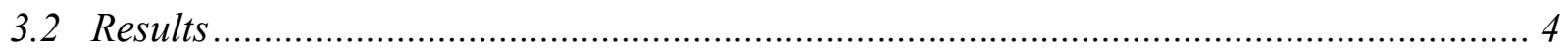

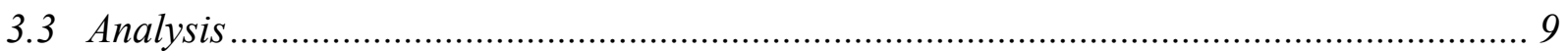

4.0 Conclusion/Summary ............................................................................................ 12

5.0 Acknowledgements.................................................................................. 13

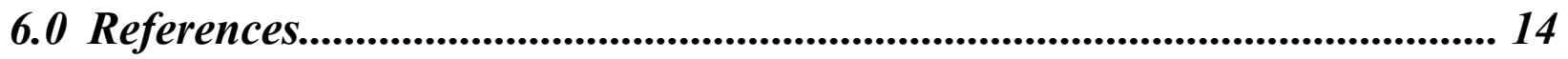

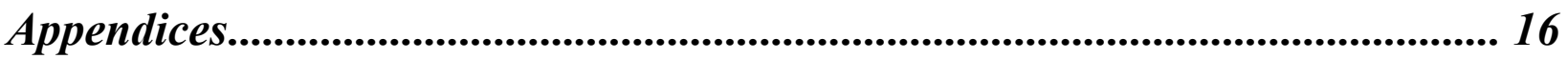

Appendix A. Experimental, DSC, and TGA Data …….................................................. 16

Appendix B. Identified Compounds in Acid-Run Liquid Phase ............................................ 31

Appendix C. X-ray Diffraction Data for SuperLig ${ }^{T M} 644$ Ion Exchange Resin ....................... 32 


\subsection{Executive Summary}

In the Hanford River Protection Project Waste Treatment Plant (RPP-WTP) flowsheet, opportunity exists for the organic SuperLig $644^{\mathrm{TM}}$ cation exchange resin to come in contact with concentrated $(5 \mathrm{M})$ nitric acid at elevated temperatures in the acid recovery evaporator. These are similar to conditions where other ion exchange resin (albeit usually anion) column explosions have occurred. The objective of these tests was to examine potential hazards by exposing the resin to conditions expected in the facility and examining the composition of the reaction products and their reactivity. As an initial examination of safety issues, experiments were carried out at the Savannah River Technology Center using an RSST $^{\mathrm{TM}}$ (Reactive System Screening Tool) where $5 \mathrm{M} \mathrm{HNO}_{3}$ was contacted with organic SuperLig $644^{\mathrm{TM}}$ cation exchange resin at 90$96^{\circ} \mathrm{C}$ for 24 hours. The results suggest that no hazards associated with solids buildup, solids reactivity, or exothermic compound generation exists, but a moderate gas generation hazard may be possible. The quantified impact of the results from these tests (and others recently reported) on facility design will be addressed in a separate document by the design authority.

\subsection{Introduction and Background}

In the Hanford River Protection Project Waste Treatment Plant (RPP-WTP) flowsheet, SuperLig $^{\text {TM }} 644$ ion exchange resin is used to remove Cs from Hanford Tank Wastes after a precipitation and cross-flow filtration pretreatment step. After Cs removal, the waste is subsequently treated to remove technetium using another IBC SuperLig ${ }^{\mathrm{TM}}$ resin. SuperLig ${ }^{\mathrm{TM}}$ 644, manufactured by IBC Advanced Technologies, Inc. of American Fork, UT, is a cesium-selective organic cation exchange resin designed for use at ambient conditions. After Cs is adsorbed onto SuperLig $^{\text {TM }} 644$ resin columns, the column is then to be regenerated using dilute nitric acid $(0.5$ $\mathrm{M} \mathrm{HNO}_{3}$ ). For process economic reasons, the resin must be able to survive at least 10 loading and elution cycles before replacement. The eluate acid is concentrated to 5.0 to $8 \mathrm{M}$ in an evaporator operating under vacuum at an approximate $50-55^{\circ} \mathrm{C}$ peak temperature, and the dilute acid in the overheads $(\sim 0.5 \mathrm{M})$ is reused as an eluant.

During the ion exchange resin elution process, a small fraction of ion exchange resin beads are expected to degrade to produce fines which can leave the column and potentially accumulate in the evaporator. Mechanisms for bead degradation include radiolytic degradation of the polymeric resin material during waste processing, physical breakdown due to resin swelling during the regeneration step, and chemical breakdown due to chemical exposure during the loading and elution steps. Previous work by Fauske and Associates has demonstrated the reactivity of SuperLig ${ }^{\mathrm{TM}} 644$ and nitric acid. Fauske had made verbal reports of SuperLig ${ }^{\mathrm{TM}} 644$ immediately "fizzing" on contact with $5 \mathrm{M} \mathrm{HNO}_{3}$. This was confirmed at the Savannah River Technology Center (SRTC), where it was noted that a colorless gas was evolved and that the resin bead color remained unchanged after exposures of several minutes. Fauske ${ }^{1}$ also conducted experiments in an $\operatorname{RSST}^{\mathrm{TM}}$ (Reaction System Screening Tool) exposing both SuperLig ${ }^{\mathrm{TM}} 639$ and 644 to $12 \mathrm{M} \mathrm{HNO}_{3}$. In $12 \mathrm{M} \mathrm{HNO}_{3}$, when mixed at a $1.15: 1$ resin mass ratio, rapid heat-up 
(over 1-5 minutes) of the resulting mixtures to over $100^{\circ} \mathrm{C}$ was reported, with faster heat-ups and higher temperatures encountered in the high pressure (300 psig, 20.7 bar initial pressure) experiments.

Technical literature has also shown that organic ion exchange resin/nitric acid reactions can lead to ion exchange column vessel rupture, fire and/or explosion. The majority of literature relates to anion exchange resins, but increasingly more data has appeared for cation exchange resins. Ion exchange column incidents have occurred at relatively modest temperatures $\left(25-90^{\circ} \mathrm{C}\right)$, although usually high column temperature and/or high acid concentrations were encountered in these cases $^{2}$. Shippy ${ }^{3}$ did note that evidence suggests that column explosions usually occur due to gas generation and not explosion of nitrated resins. Kalkwarf ${ }^{4}$ found no literature suggesting commercial cation-exchange resins (with styrene-divinylbenzene, phenol-formaldehyde, and acrylic acid-divinylbenzene backbones) can detonate and viewed the possibility unlikely given the resin chemical structures. Due to the proprietary nature of the SuperLig ${ }^{\text {TM }} 644$ cation exchange resin structure, a structural analysis could not be independently performed. Kalkwarf also emphasized that the commercial cation-exchange resins studied can generate key requirements for a thermal explosion, both heat and gas, upon reaction with strong oxidants such as nitric acid.

The literature and the expectation that resin fines could come into contact with concentrated nitric acid at elevated temperatures in the acid recycle evaporator indicate the strong possibility of acid/resin reactions. Combined with the unknown chemical structure of SuperLig ${ }^{\text {TM }}$ 644, strong motivation exists to study possible explosion scenarios resulting from gas generation from the reaction of nitric acid with resin fines and from the detonation of nitrated resin or resin degradation products. The objectives of this work were to simulate the extended presence of SuperLig $^{\mathrm{TM}} 644$ cation exchange resin in the nitric acid evaporator, and to serve as an initial survey for safety issues related to gas generation or exothermic compound formation due to the reaction of SuperLig ${ }^{\mathrm{TM}} 644$ with nitric acid. The chemical reactivity examined here should be directly applicable to the RPP-WTP process, although it may not encompass all possible reaction scenarios. Additional work in related areas has been completed and is reported elsewhere.

This task fulfills all the requests as defined in Task Technical Plan BNF-003-98-0163. Quality Assurance requirements were applied to this work as described in Nash, C. A., McCabe, D. J., "Technical Task and Quality Assurance Plan: Studies of Ion Exchange Resin Integrity under Flowsheet Extremes", BNF-003-98-00163, Rev. 0, September 21, 1999.

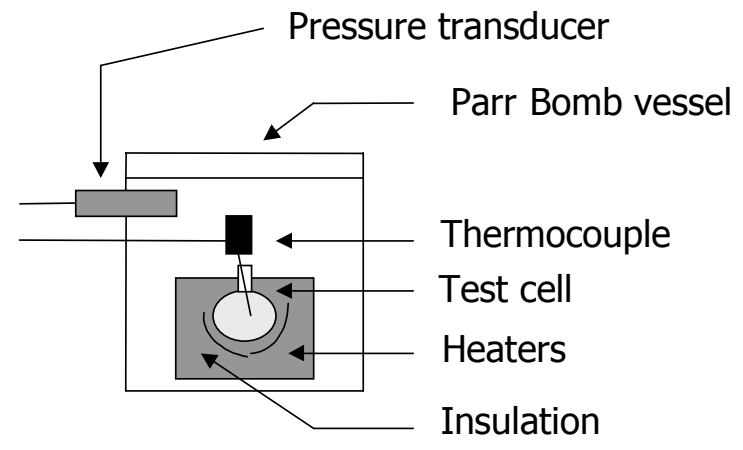

Figure 1. Reactive System Screening Tool $^{\mathrm{TM}}$ $\left(\mathrm{RSST}^{\mathrm{TM}}\right.$ ) schematic. 


\subsection{Discussion}

\subsection{Experimental}

Due to its use in the sizing of pressure relief valves and the inherent safety of its design (temperature and pressure containment), the Reactive System Screening Tool ${ }^{\mathrm{TM}}$ $\left(\mathrm{RSST}^{\mathrm{TM}}\right)$ manufactured by Fauske and Associates was selected for this experimental work (Figures 1 and 2). The apparatus consists of an approximately $12 \mathrm{~mL}$ glass test cell lined by electrical heaters contained within an insulated aluminum "can". A thermocouple to measure the sample temperature is inserted into the test cell from above before the Parr Bomb is closed. A computer is used to monitor and record sample temperature and bomb pressure, and control electrical power to the sample heaters. The sample is mixed using a magnetic stir bar and stirrer.

After this testing was completed, the resin manufacturer

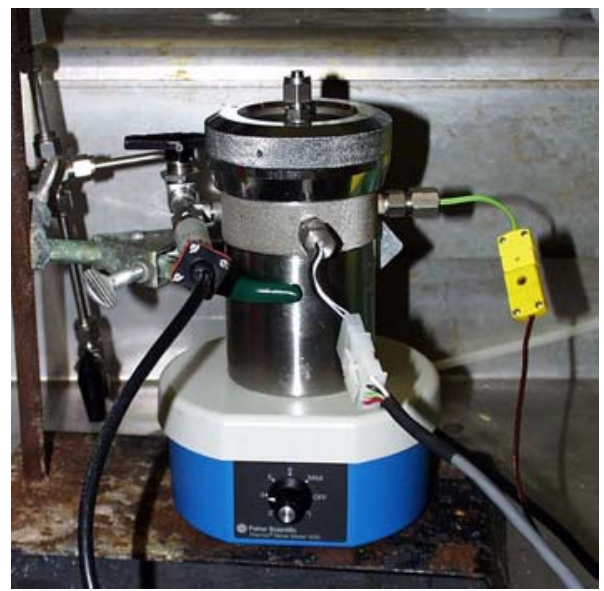

Figure 2. Picture of the Reactive System Screening Tool ${ }^{\mathrm{TM}}\left(\mathrm{RSST}^{\mathrm{TM}}\right)$. revealed that the resin contains a significant fraction of potassium carbonate and/or bicarbonate as a result of the manufacturing process. In this study, $0.4 \mathrm{~g}$ SuperLig ${ }^{\mathrm{TM}} 644$ cation exchange resin was loaded into the test cell. It must be noted here that in this early RSST work the resin was being used as-received. It was not pretreated with nitric acid. Therefore, contaminant potassium bicarbonate was still in the resin that was used for this work. It would account for 35 to 50 weight percent resin mass loss when the resin was exposed to even water or weak acid.

After closing the Parr bomb, $10 \mathrm{~g}$ of either $5 \mathrm{M} \mathrm{HNO}_{3}$ or de-ionized water (investigative blank) was injected into the test cell through a port on the Parr Bomb cap. Although the RSST vent valve was closed immediately after liquid injection and the injection port closed before removal of the syringe used for liquid injection, it cannot be ruled out that gases generated instantaneously when the acid was injected escaped without quantification. A 25:1 liquid-to-solid mass ratio was selected as a reasonably practical and order-of-magnitude realistic mixture of resin fines and acid expected to be encountered in the acid recycle evaporator in the RPP-WTP process. As explained in the Results section, the minimum $0.25^{\circ} \mathrm{C} / \mathrm{min}\left(15^{\circ} \mathrm{C} / \mathrm{hr}\right) \mathrm{RSST}^{\mathrm{TM}}$ heat-up rate was employed to a peak temperature of $90-96^{\circ} \mathrm{C}$ which was maintained for 24 hours to simulate prolonged residence time in the evaporator. The mixture was allowed to gradually cool to room temperature afterwards. The $90-96^{\circ} \mathrm{C}$ peak temperature was chosen to permit the same hold temperature to be used for both the acid and de-ionized water experiments at atmospheric pressure. Atmospheric pressure was used to reduce evaporation of the liquid during the experiment, and permitted gas generation estimation without using estimated Parr bomb air inleakage rates. All tests utilized SuperLig ${ }^{\circledR} 644$ batch \# 981020MB48-563, as received. 
After the mixture cooled to ambient, the test cell was removed from the Parr Bomb. After weighing the post-run test cell contents, the remaining liquid in the test cell was decanted using a pipette. The remaining resin residue was rinsed three times with de-ionized water $(>5: 1$ water to residue mass ratio) prior to removal from the test cell.

For analysis of the post-run gas, the pressurized Parr Bomb was vented into a Tedlar gas sample bag, which was sent for fixed gas and volatiles analysis by gas chromatography-mass spectrometry (GC-MS). After the rinsed residue was dried on a watchglass at ambient conditions until constant weight, samples were sent for differential scanning calorimetry (DSC) and thermogravimetric (TGA) analyses using Thermal Analyzer (TA) Instruments, Inc., Models DSC-910 and TGA-951, respectively, to look for exothermic characteristics. Three-milliliter aliquots of the decanted liquids were also dried to a constant weight on watchglasses at ambient conditions. The resulting dried dissolved solids were also sent for DSC and TGA analysis.

\subsection{Results}

SuperLig ${ }^{\mathrm{TM}} 644$ samples which had been heated in $5 \mathrm{M} \mathrm{HNO}_{3}$ to $>90^{\circ} \mathrm{C}$ completely dissolved, leaving no solid residue for analysis. To examine formation of exothermic nitrated organic compounds, a shortened run was performed using a heating rate of $0.4^{\circ} \mathrm{C} / \mathrm{min}\left(25^{\circ} \mathrm{C} / \mathrm{hr}\right)$, and DSC analysis was carried out on the resulting partially-reacted residue. An exotherm which began at $55-65^{\circ} \mathrm{C}$ caused acid boil-off at $110^{\circ} \mathrm{C}$. However a few milligrams of a fine bright yellow residue, contrasting with the dark purple/brown beads of fresh SuperLig ${ }^{\text {TM }} 644$ loaded initially, remained. This material was collected, divided and duplicate DSC scans were performed. The scans yielded endotherms but no exotherms in the heat flow profile. From this result, it was concluded that no additional hazards from reacted residues exist in the early stages of resin breakdown, although it was not feasible to separate and test the soluble breakdown products in this experiment.

The exotherm observed during the heat-up did impact experimental operations of the $\mathrm{RSST}^{\mathrm{TM}}$ and caused a deviation from the original Technical Task Plan ${ }^{5}$ (TTP). To allow for automated operation of the RSST, the heating rate was reduced to the minimum allowable heating rate of $15^{\circ} \mathrm{C} / \mathrm{hr}$, deviating from the TTP's specified $20-25^{\circ} \mathrm{C} / \mathrm{hr}$. Despite this modification, the energy release from the exothermic reaction still caused the resin/acid mixture to boil over and out of the test cell, requiring manual shut-offs during the heat-up stage. This accounts for the spike observed in the heat-up profile in the acid run data to be discussed later.

In the investigative "blank" or reference runs with SuperLig ${ }^{\text {тм }} 644$ and de-ionized water, a redbrown liquid phase was produced (Figure 3, center vial). This result is consistent with previous SRTC observations when prolonged ambient-temperature exposure of SuperLig ${ }^{\text {TM }} 644$ in water produced dark solutions. The remaining solid did not display visible resin bead degradation. Typical temperature and pressure profiles are shown in Figure 4. A clean heat-up profile was 
obtained where the actual temperature matched the program reasonably well. A small dip during the hold at 1300 minutes was due to the drop in $\mathrm{RSST}^{\mathrm{TM}}$ temperature during the resetting of the computer program that is required to achieve a 24 hour hold time. Average peak temperatures for the two reference runs were both $93^{\circ} \mathrm{C}$. Only a $5 \%$ rise ( $\sim 0.8 \mathrm{psig}, \sim 0.055$ bar $)$ in system pressure was observed, caused by a calculated $16^{\circ} \mathrm{C}$ temperature increase in the Parr Bomb interior air.

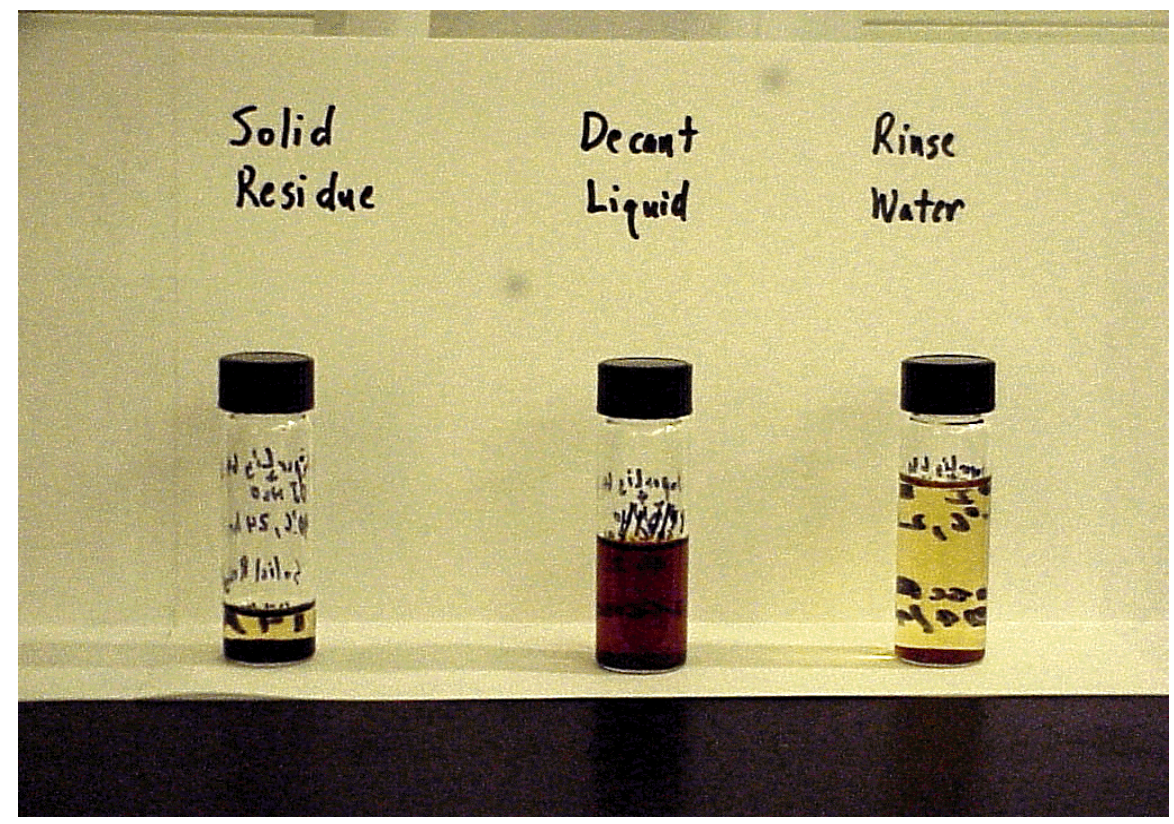

Figure 3. Typical products from the de-ionized water/SuperLig ${ }^{\mathrm{TM}} 644$ tests. 


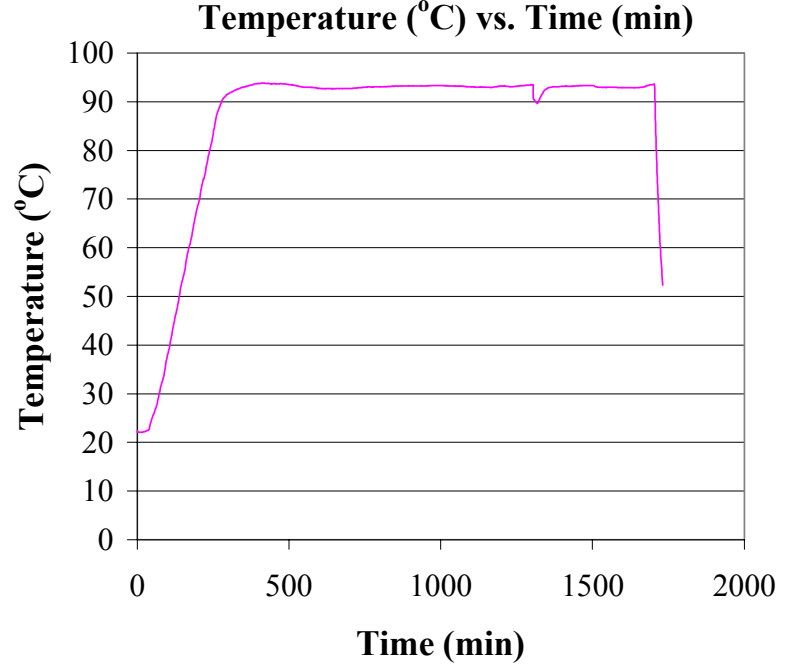

Pressure (bar - gauge) vs. Time (min)

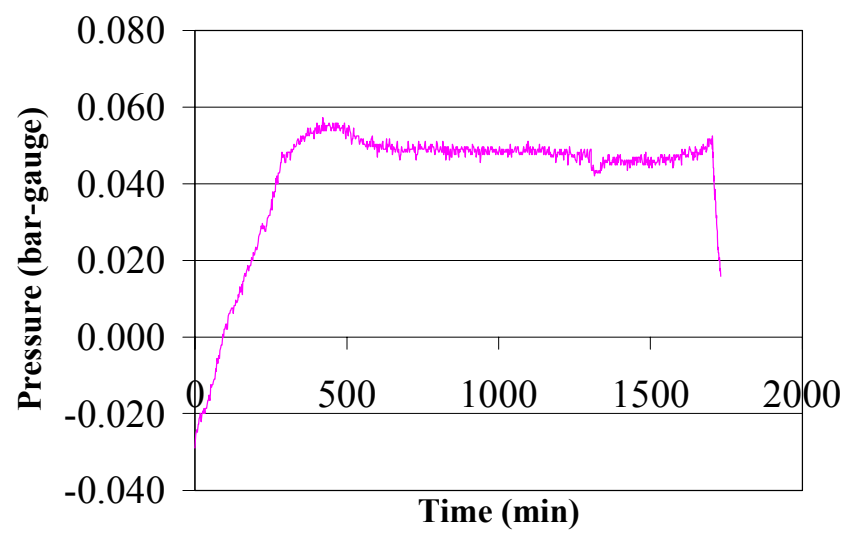

Heatup Only

Temperature $\left({ }^{\circ} \mathrm{C}\right)$ vs. Time (min)

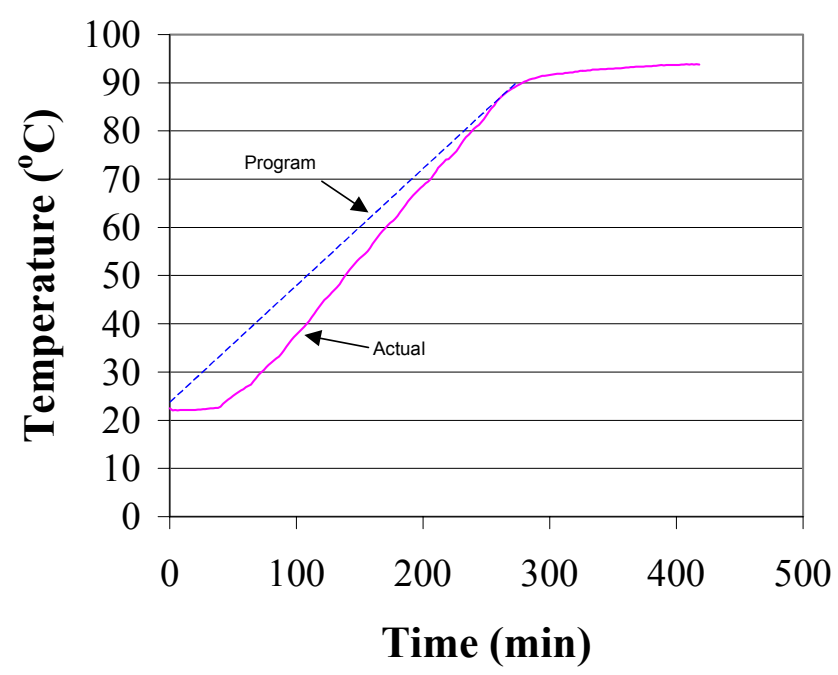

Figures 4. Typical temperature and pressure profiles in the de-ionized water/ SuperLig ${ }^{\mathrm{TM}} 644$ tests. 
These observations seen in the "blank" runs strongly contrast those in the SuperLig " $644-5 \mathrm{M}$ $\mathrm{HNO}_{3}$ runs. Significant reaction was observed where only a bright yellow liquid phase remained after 24 hours at $90-96^{\circ} \mathrm{C}$ (Figure 5). No solid residue was obtained suggesting total digestion of the original resin material. Figure 6 shows the typical temperature and pressure profiles obtained during these acid runs. As in the shortened test discussed earlier, exotherms beginning at 50$60^{\circ} \mathrm{C}$ were observed in the duplicate runs whose peak temperatures were 90 and $96^{\circ} \mathrm{C}$. The peak during the heat-up is due to the exotherm and coincided with the manual shut-off of the heat input into the $\mathrm{RSST}^{\mathrm{TM}}$ to avoid acid boil-off. Otherwise, a clean temperature profile was obtained. Continuous gas generation and a near doubling of the system pressure was also seen, with an estimated $280 \mathrm{~mL}$ of gas (calculated at STP) generated from $0.4 \mathrm{~g}$ resin in a Parr Bomb with an internal volume of $340 \mathrm{~cm}^{3}$.

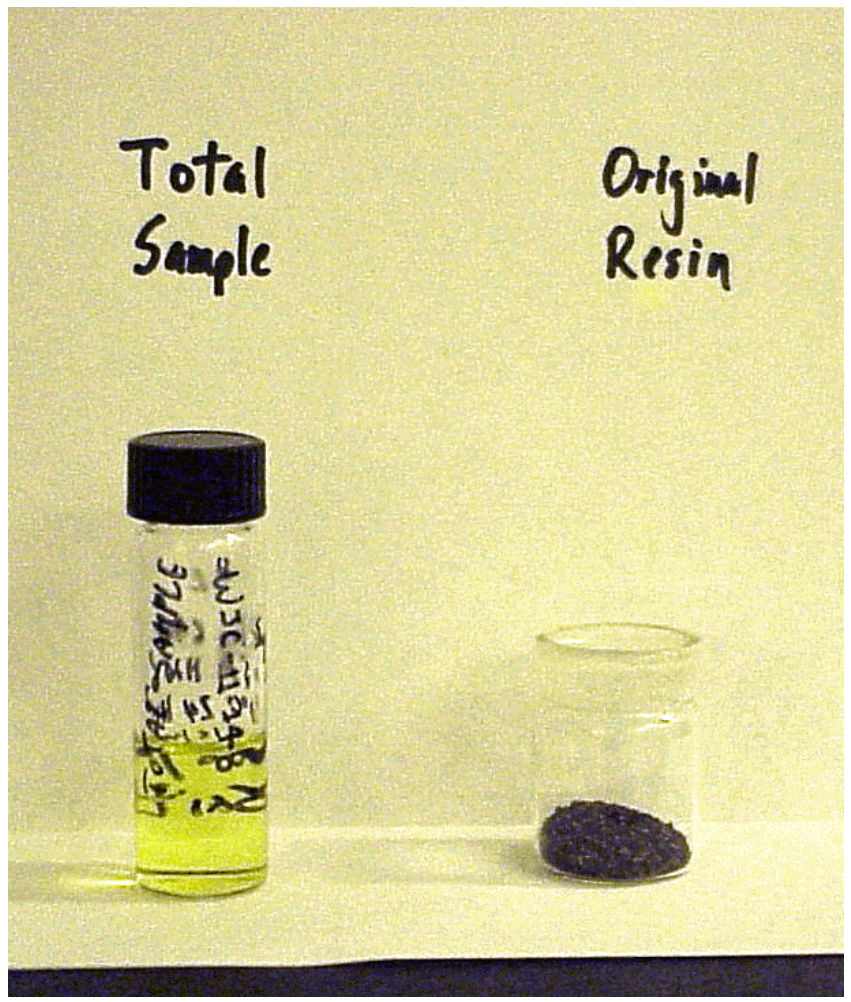

Figure 5. Typical products from the $5 \mathrm{M}$ nitric acid/ SuperLig ${ }^{\mathrm{TM}} 644$ tests. 


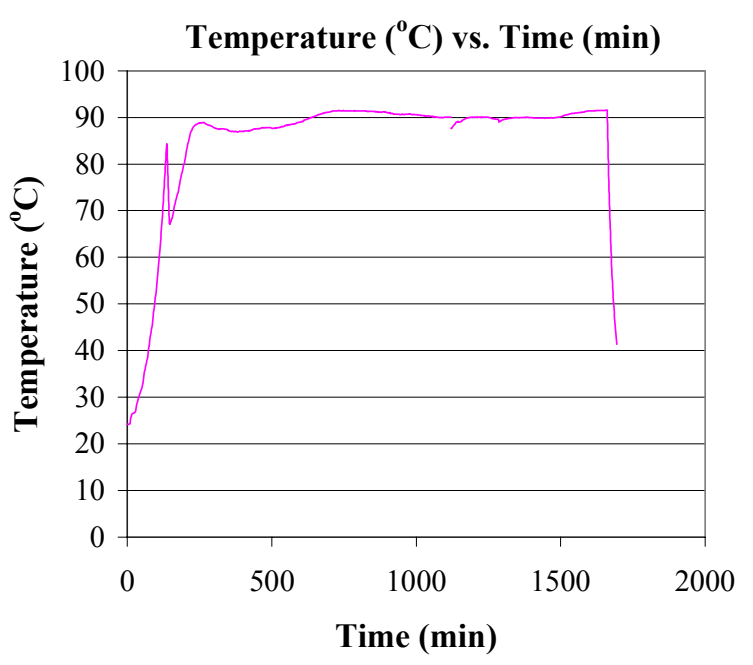

WSRC-TR-2000-00411

SRT-RPP-2000-00027

Pressure (bar-gauge) vs. Time (min)

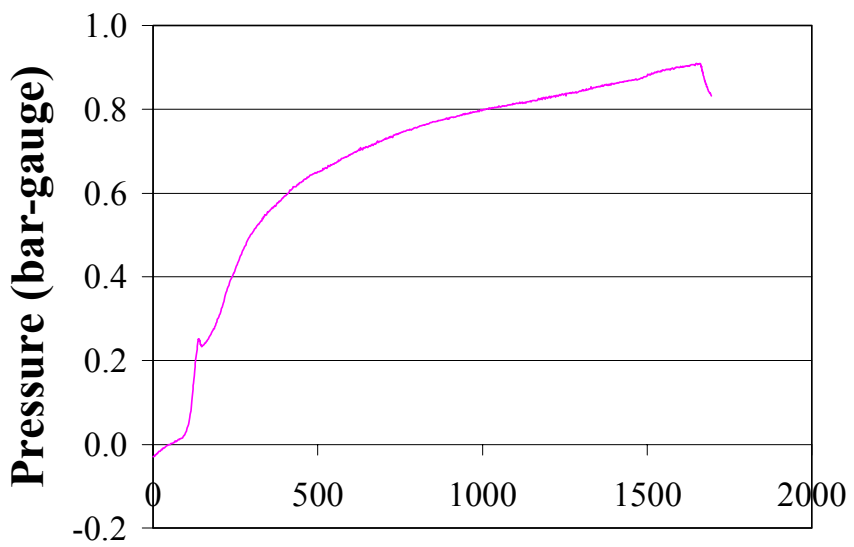

Time (min)

Heatup Only

Temperature $\left({ }^{\circ} \mathrm{C}\right)$ vs. Time (min)

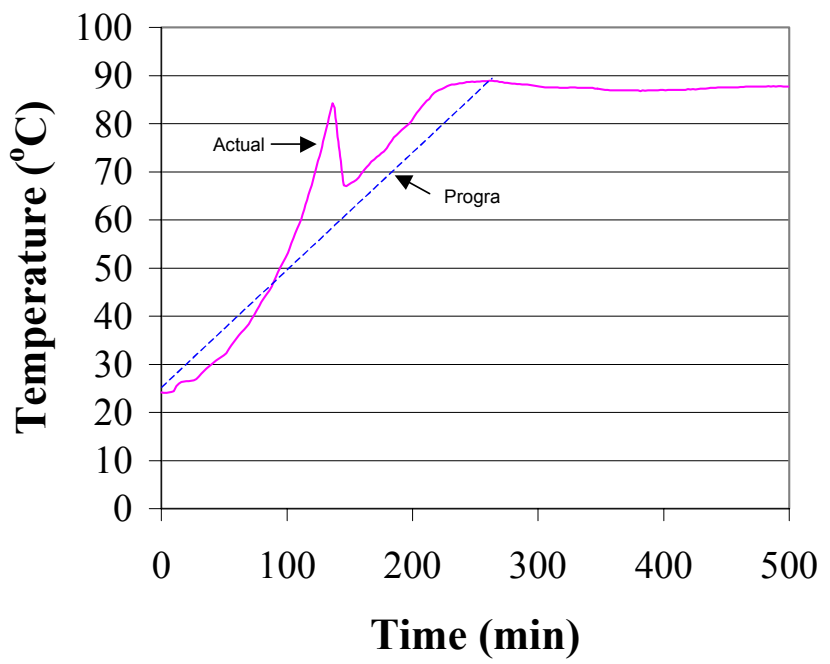

Figure 6. Typical temperature and pressure profiles in the $5 \mathrm{M} \mathrm{HNO}_{3} /$ SuperLig $^{\mathrm{TM}} 644$ tests. 
A separate resin/acid run with the same initial resin and acid masses was performed to generate gas for GC-MS analysis for fixed gases and volatile organic compounds. After the Parr bomb was allowed to cool to $25^{\circ} \mathrm{C}$ in this run, a final pressure of 14.93 psig (1.03 bar) was observed before the excess pressure was vented into a Tedlar gas sampling bag. The analytical results are shown in the middle column of Table 1 . The primary products were nitrogen and carbon oxides (NO and $\mathrm{CO}_{2}$ ), and nitrous oxide $\left(\mathrm{N}_{2} \mathrm{O}\right)$ with traces of carbon monoxide. Only trace quantities of volatile organic compounds were observed with individual component concentrations less than $110 \mu \mathrm{g} / \mathrm{L}$ (see Appendix B).

\begin{tabular}{|c|c|c|c|c|}
\hline GAS & $\begin{array}{c}\text { Initial Volume, } \\
\mathrm{mL}^{*}\end{array}$ & Final Volume, mL & $\begin{array}{c}\text { Final Composition } \\
\text { (volume percent) }\end{array}$ & $\begin{array}{c}\text { mL Generated by } \\
\text { Resin + nitric }\end{array}$ \\
\hline $\mathrm{N}_{2}$ & 261.0 & 261.0 & Not measured & 0. \\
\hline $\mathrm{O}_{2}$ & 70.3 & 0 . & 0.0 was measured & 0 . \\
\hline $\mathrm{Ar}$ & 3.4 & 3.4 & Not measured & 0 . \\
\hline $\mathrm{CO}_{2}$ & 0 . & 102.9 & 15. & 102.9 (see text) \\
\hline $\mathrm{CO}$ & 0 . & 3.6 & 0.52 & 3.6 \\
\hline $\mathrm{N}_{2} \mathrm{O}$ & 0 . & 22.6 & 3.3 & 22.6 \\
\hline $\mathrm{NO}_{2}$ & 0 . & 278.2 & Calculated & $278.2-140.6=137.6$ \\
\hline $\mathrm{NO}$ & 0 . & 2.7 & 0.39 & $2.7+140.6=143.3$ \\
\hline $\mathrm{H}_{2} \mathrm{O}$ & 5.3 & 10.6 & Calculated & $0 .($ see text) \\
\hline SUM & $340 \mathrm{~mL}$ & $685 \mathrm{~mL}$ & & $410 \mathrm{~mL}$ \\
\hline
\end{tabular}

Table 1. Composition of the acid run overhead gas and the volumes of gases in the bomb at the end of the run.

\footnotetext{
${ }^{*}$ Calculated from the initial condition where the bomb was filled with air $\left(78 \% \mathrm{~N}_{2}, 21 \% \mathrm{O}_{2}, 1 \% \mathrm{Ar}\right.$, $50 \%$ relative humidity)

Gas volumes are at $25^{\circ} \mathrm{C}$ and at $14.7 \mathrm{psia}$.
}

\subsection{Analysis}

Results of analysis of Tedlar bag gas sample yielded the fourth column in Table 1. Oxygen level was measured to be zero, meaning that all the initial oxygen from air had reacted with a product from the sample. As it is known that nitric oxide (NO) rapidly reacts with $\mathrm{O}_{2}$ under ambient conditions by the reaction $2 \mathrm{NO}+\mathrm{O}_{2} \rightarrow 2 \mathrm{NO}_{2}$, corrections to the volume of total gas generated and gas composition were required. The $70.3 \mathrm{~mL}$ of $\mathrm{O}_{2}$ thus converted $140.6 \mathrm{~mL}$ of NO to a similar volume of $\mathrm{NO}_{2}$. Volume of gas at the end of the run $(685 \mathrm{~mL}, \mathrm{STP})$ was calculated using the final ambient RSST pressure prior to venting into the Tedlar bag (14.93 psig, 1.03 bar gauge) and a leak-tight Parr Bomb of $340 \mathrm{~mL}$ internal volume. Volumes of $\mathrm{CO}, \mathrm{CO}_{2}$ and $\mathrm{N}_{2} \mathrm{O}$ were 
calculated using the analytical results. Water vapor contribution $(5.3 \mathrm{~mL}$ initially at $50 \%$ relative humidity and $10.6 \mathrm{~mL}$ at $100 \%$ final relative humidity) was estimated assuming the final gas at 14.93 psig (1.03 bar gauge) was saturated with water vapor. Nitrogen and argon in the Parr Bomb from initial air was assumed inert, and the end of run nitrogen dioxide $\left(\mathrm{NO}_{2}\right)$ was calculated by difference. The end of run $\mathrm{NO}_{2}$ and $\mathrm{NO}$ were lastly corrected for complete reaction of initial oxygen $(70.3 \mathrm{~mL})$ with $\mathrm{NO}$, to yield the volumes of generated gas in Table 1. The large volume of gas generated $\left(410 \mathrm{~mL}\right.$ final volume at $25^{\circ} \mathrm{C}$ and at 14.7 psia) strongly suggests that significant off-gas will be generated in the evaporator which must be treated.

However after this testing was completed, the resin manufacturer revealed that the resin contains a significant fraction of potassium carbonate and/or bicarbonate as a result of the manufacturing process. Crooks et al. ${ }^{6}$ quantified the potassium-only content to be $15.5 \mathrm{wt} \%$ of "as-received" resin. Hassan clearly confirmed by X-ray diffraction that potassium bicarbonate is the form present in "as-received" resin (spectra in Appendix C). Assuming all potassium was present as $\mathrm{KHCO}_{3}$ and assuming complete reaction with excess acid (supported by the observed initial vigorous "fizzing" of the resin upon addition of $5 \mathrm{M} \mathrm{HNO}_{3}$ ), the maximum carbon dioxide contribution from residual bicarbonate was calculated to be $39 \mathrm{~mL}$. This would account for up to $38 \%$ of the detected quantity of $\mathrm{CO}_{2}$ (Table 1). The potassium level reveals that up to $40 \mathrm{wt} \%$ of "as-received" resin may be potassium bicarbonate, and reduces $\mathrm{CO}_{2}$ generation from organic resin carbon oxidation to $63.9 \mathrm{~mL}$. This $63.9 \mathrm{~mL}$ of $\mathrm{CO}_{2}$ represents $0.031 \mathrm{~g}$ of carbon or about $8 \%$ of the initial resin mass. Another implication of these assumptions is that up to $3.6 \%$ of the initial acid in the added $5 \mathrm{M} \mathrm{HNO}_{3}$ was consumed during the initial "fizzing", reducing the acid molarity to about 4.8 M. Other sources of gaseous species cannot be precisely attributed due to the proprietary nature of the ion exchange resin chemical composition. If the true amount of resin is considered to be $0.24 \mathrm{~g}(0.4 \mathrm{~g}$ minus the potassium bicarbonate $)$ and if the amount of gas released is $410 \mathrm{~mL}$ minus the $39 \mathrm{~mL}$ from bicarbonate, then dissolving resin in nitric acid produced $1550 \mathrm{~mL}$ of gas per $\mathrm{g}$ of resin. The amount of water produced when resin is dissolved is unknown, but amount of water vapor production is controlled by thermal processes. This is true because water is a condensable product in contrast to the other gaseous products.

After the RSST experiments were completed, the remaining liquid phase was decanted (pipetted) from the remaining residual solids phase. In the acid runs, only a liquid sample existed since the resin was completely digested during the experiment, as noted previously. The separated liquid and solid phases (if present) were then placed in separate watch glasses. They were dried to constant weight over a period of several days in a fume hood at ambient conditions to recover all possible solids from the experiment and to obtain an estimate of the percentage of resin converted to gas during each experiment. Based on this work, a resin material balance was performed for each of the $5 \mathrm{M} \mathrm{HNO}_{3}$ or de-ionized water with SuperLig ${ }^{\mathrm{TM}} 644$ experiments (Table 2). Mass balance closures of $64-65 \%$ and $99-102 \%$ were obtained for the acid and water runs, respectively. The acid run mass balance closures could not be improved due to the uncertainty of the sources of the gas components. The most interesting result of this calculation is that slightly more than half of the initial resin dissolved in de-ionized water at 25:1 liquid-tosolid ratios at $93^{\circ} \mathrm{C}$, an outcome that has been confirmed by similar studies by Crooks et al. ${ }^{7}$ 
This is consistent with recent revelations by the vendor that substantial potassium and other water-soluble components are present after manufacture of the resin.

\begin{tabular}{|c|c|c|c|c|c|}
\hline & & & Mass Balance & \% Initial Resin \\
\hline & Initial Resin (g) & Final Resin (g) & Dissolved Solids (g) & Closure (\%) & as Dissolved Solids \\
\hline Acid Run \#1 & 0.402 & 0 & 0.2590 & 64.4 & 64.4 \\
\hline Acid Run \#2 & 0.401 & 0 & 0.2582 & 64.4 & 64.4 \\
\hline & & & & & \\
\hline Water Run \#1 & 0.406 & 0.1951 & 0.2072 & 99.1 & 51.0 \\
\hline Water Run \#2 & 0.400 & 0.1923 & 0.2136 & 101.5 & 53.4 \\
\hline
\end{tabular}

Table 2. Mass balance closure summary and percentage of initial resin as dissolved solids

DSC and TGA analyses of the solid residues and dried dissolved solids were performed (See Appendix A for raw data). DSC of the dried dissolved solids from the acid runs showed no detonation but significant exotherms (67 - $148 \mathrm{~J} / \mathrm{g}$ by peak integration) over a period of roughly 4-7 minutes. The maximum observed energy release $(148 \mathrm{~J} / \mathrm{g})$ is almost a factor of 30 less than the energy from the detonation of trinitrotoluene ${ }^{8}$ (TNT) which is $4295 \mathrm{~J} / \mathrm{g}$. The length of time for energy release is comparable to the smaller of two exothermic peaks observed by Duh et al. ${ }^{9}$ for ammonium nitrate, where $373 \mathrm{~J} / \mathrm{g}$ was released over a period of nearly 6 minutes. The observed energy release was much slower than ammonium nitrate's larger exotherm evolving nearly $910 \mathrm{~J} / \mathrm{g}$ in approximately 1 minute. The energy release for each exotherm measured by Duh was manually integrated by the full-width half-maximum integration technique, and the total energy release compares well with the the literature value of $470-2000 \mathrm{~J} / \mathrm{g}$ heat of reaction range for various possible ammonium nitrate decomposition reactions ${ }^{10}$.

The "gummy" nature of the acid-run dried dissolved resin solids suggests that residual nitric acid may have been present as a nitric acid-water azeotrope (66.7-68.7 $\mathrm{wt} \% \mathrm{HNO}_{3}, 75-1200 \mathrm{~mm}$ $\left.\mathrm{Hg}^{11}\right)$, contributing to the exothermic characteristics. One dried dissolved solids sample was vacuum dried at ambient temperature for over 36 hours and tested by DSC again to reduce the influence of any residual nitric acid and moisture remaining in the solid as a result of the ambient watchglass drying method. The solids texture remained unchanged as a result of extended vacuum drying, but the exothermic energy release was found to decrease from $146 \mathrm{~J} / \mathrm{g}$ to $101 \mathrm{~J} / \mathrm{g}$ and the initial large single peak may have been resolved into 2-3 separate exotherms. TGA profiles of the acid run dried dissolved solids were unremarkable. The majority of the mass loss, $\sim 10-15 \mathrm{wt} \%$, was complete before the $2-5 \mathrm{wt} \%$ mass loss during the DSC exotherms, indicating that minimal gases were generated as a result of exothermic degradation of the acid-run dried dissolved resin solids.

Also observed in the acid run dried dissolved solids DSC scans were $5.5-36 \mathrm{~J} / \mathrm{g}$ endotherms in the $120-140^{\circ} \mathrm{C}$ range which could be attributable to delayed $68 \mathrm{wt} \%$ nitric acid $-32 \mathrm{wt} \%$ water azeotrope release from the sample $\left(120.5^{\circ} \mathrm{C}\right.$ boiling point at $\left.735 \mathrm{~mm} \mathrm{Hg}{ }^{12}\right)$, or to phase transitions at $129^{\circ} \mathrm{C}^{13}$ of solid potassium nitrate. Up to $40 \mathrm{wt} \%$ residual potassium nitrate may be present in the resin due to nitric acid reacting with residual potassium from the resin synthesis process. DSC of the dried dissolved solids from the water runs showed no exotherms, and scans of the dried solid residues showed only a large endotherm at $100^{\circ} \mathrm{C}$ likely associated with the 
release of moisture. TGA profiles of all water run samples were unremarkable and showed continuous weight loss, with the solid residues showing a more constant weight loss rate throughout the analysis. The DSC and TGA temperature-time programs were both $5^{\circ} \mathrm{C} / \mathrm{min}$ to $300^{\circ} \mathrm{C}$ with no hold at peak temperature.

GC-MS analysis of the gas and the liquid phases also yielded valuable information. Analysis of the liquids produced from the acid runs found no nitrated compounds among the two identifiable components (see Appendix B). These compounds were found at $0.28-0.40 \mathrm{mg} / \mathrm{L}$ concentrations. To ensure the absence of nitrated compounds, it was confirmed that the NIST Library in the GCMS computer used to analyze these compounds contains a database of common nitrate explosives such as methyl nitrate, TNT, nitroglycerin, and butyl nitrate. Other unidentifiable compounds were found in the $0.09-1.4 \mathrm{mg} / \mathrm{L}$ concentration ranges. GC-MS of the acid run gas samples showed trace quantities of volatile organic compounds in the $12-110 \mu \mathrm{g} / \mathrm{L}$ range with several trace hydrocarbons components (see Appendix B). A blank run with just $5 \mathrm{M} \mathrm{HNO}_{3}$ in the RSST $^{\mathrm{TM}}$ test cell undergoing the same temperature-time history showed that one-third to about one-half of two identified volatiles are generated from the degradation of RSST ${ }^{\mathrm{TM}}$ internals, such as wiring insulation, electrical tape, and vacuum grease. It is likely that toluene and 3methylhexane originated entirely from the $\operatorname{RSST}^{\mathrm{TM}}$ internals or the sampling equipment.

Total organic carbon (TOC) analysis of acid run and water run liquids was also performed, but the large scatter in the data (5400-6500 ppm for acid runs, 5700-6200 ppm for water runs) indicated no significant difference between the two types of samples.

The Analytical Development Section (ADS) analyzed sample chemistry per quality assurance requirements as well as tracking samples within the LIMS system. ADS analyzed liquid samples by SVOC and gaseous samples by VOA Halocarbon ( $5 \mathrm{~mL}$ purge/trap) and VOA Halocarbon (direct gas loop). These organic analysis methods are consistent with EPA SW-846 methods, although the laboratory is not certified by the South Carolina Department of Health and Environmental Control for NPDES discharge compliance monitoring.

\subsection{Conclusion/Summary}

This investigation has shown the following regarding the hazards of exposing SuperLig ${ }^{\mathrm{TM}} 644$ cation exchange resin to $5 \mathrm{M} \mathrm{HNO}_{3}$ at $90-96^{\circ} \mathrm{C}$ over a 24 hour period:

- Solids in the evaporator

- Introduction of resin fines to $5 \mathrm{M} \mathrm{HNO}_{3}$ at $55^{\circ} \mathrm{C}$ or higher will cause an exothermic reaction. 
- Solids buildup from resin fines in the evaporator is unknown although SuperLig ${ }^{\mathrm{TM}} 644$ was completely digested in $5 \mathrm{M} \mathrm{HNO}_{3}$ at $>90^{\circ} \mathrm{C}$.

- DSC of partially digested resin did not show any exotherms, indicating no dangers associated with nitration of the resin

- Gas generation

- Significant gas $\left(\mathrm{NO}_{\mathrm{x}}, \mathrm{CO}_{2}\right)$ generation was observed, indicating the need for allowance in the off-gas system for the evaporator. Calculations of the pressure release system are the responsibility of the design authority.

- Heat generation was observed but was not self-sustaining, as shown by the manual heater shutdowns.

- Liquids hazards

- In the DSC scans, none of the dried dissolved solids displayed exotherms indicative of detonation, suggesting no nitration-related hazards are introduced into the evaporator liquids.

- The absence of identifiable volatile and semi-volatile nitrated organics was confirmed by GC-MS analysis. However, resin dissolution would still need to be addressed when quality of recycled nitric acid is considered.

- As confirmed in a subsequent study, approximately half of the resin was dissolved in de-ionized water after 24 hours at elevated temperature. This is largely attributable to the large quantity of potassium bicarbonate in the as-received SuperLig ${ }^{\circledR} 644$ (Batch \# 981020MB48-563) resin.

\subsection{Acknowledgements}

The authors wish to thank Don Burge and Elaine Pearson for their help in preparing the dried samples, Paul Korinko for the DSC and TGA analyses of the residues and dried dissolved solids, John Young and Steve Crump for their GC-MS work on gas and liquid samples, Neguib Hassan and Art Jurgensen for their X-ray diffraction work identifying potassium bicarbonate in the "asreceived" SuperLig ${ }^{\mathrm{TM}} 644$ resin, Amy Ekechukwu for her TOC analysis work, and Mark Crowder for his timely help operating the RSST. 


\subsection{References}

1. Fauske, H. F., "BNFL Resin - Nitric Acid Tests: Pressure Relief Requirements; Rev. 1", Appendix 4D, Fauske Report No. FAI/99-68, 16W070 West $83^{\text {rd }}$ St., Burr Ridge, IL 60521, July 27, 1999.

2. Calmon, C., "Explosion Hazards of Using Nitric Acid in Ion-Exchange Equipment", Chemical Engineering, 87, pp. 271-4, November 17, 1980.

3. Shippy, P. J., " $\mathrm{HNO}_{3}$-Anion/Cation Resin Exchange Column Pressure Relief", internal Dupont/SRTC memo, Aiken, SC 29808, July 3, 1985.

4. Kalkwarf, D. R., "Safety Evaluation of Cation-Exchange Resins", Report No. BNWL-2391 UC-10, Battelle Pacific Northwest Laboratories, Richland, WA 99352, August, 1977.

5. Nash, C. A., McCabe, D. J., "Technical Task and Quality Assurance Plan: Studies of Ion Exchange Resin Integrity under Flowsheet Extremes", BNF-003-98-00163, Rev. 0, September 21, 1999.

6. Crooks, III, W. J., Nash, C. A., McCabe, D. J., Saito, H. H., "Studies of Ion Exchange Resin Integrity under Flowsheet Extremes: Part II", WSRC-TR-2000-00304, SRT-RPP-2000-00005, formerly BNF-003-98-0312, December, 2000.

7. Crooks, III, W. J., Nash, C. A., McCabe, D. J., Saito, H. H., ibid., December, 2000.

8. Grewer, T., "Thermal Hazards of Chemical Reactions", Industrial Safety Series 4, pg. 393, Elsevier, Amsterdam, 1994.

9. Duh, Y. S., Lee, C., Hsu, C. C., Hwang, D. R., Kao, C. S., "Chemical Incompatibility of Nitrocompounds", Journal of Hazardous Materials, 53, pp. 183-94, 1997.

10. Federoff, B. T., Aaronson, H. A., Reese, E. F., Sheffield, O. E., Clift, G. D., "Ammonium Nitrate (AN)", Encyclopedia of Explosives and Related Items, Vol. 1, pp. 319-20, U.S. Army Research and Development Command, Warheads, Energetics and Combat Support Center, Picatinny Arsenal, New Jersey, 1960.

11. Azeotropic Data - Tables of Azeotropes and Nonazeotropes, Advances in Chemistry Series, Vol. 6, pg. 5, American Chemical Society, Washington, D.C., 1952.

12. Azeotropic Data - Tables of Azeotropes and Nonazeotropes, ibid.

13. "Kaliumnitrat", Gmelins Handbuch der Anorganischen Chemie - Kalium, Vol. 22, pp. 278-81, Verlag Chemie, GmBH., Berlin, 1953. 
DISTRIBUTION:

H. F. Sturm

J. C. Marra

C. T. Randall

L. M. Nelson

RPP-WTP File

W. J. Crooks

N. M. Hassan

M. C. Thompson 


\section{Appendices}

\section{Appendix A. Experimental, DSC, and TGA Data}

\section{Experimental Data and Material Balance Summary}

\begin{tabular}{|c|c|c|c|c|c|c|c|c|c|c|c|c|c|c|c|c|}
\hline \multicolumn{17}{|c|}{ SuperLig 644/Nitric Acid Stability Study Experimental Data } \\
\hline Hiroshi Satio & & & & & & & & & & & & & & & & \\
\hline $\begin{aligned} 31 / 10100 \\
\end{aligned}$ & & & & & & & & & & & & & & & & \\
\hline Acid Runs & & & & & & $\begin{array}{l}\text { \% Material } \\
\text { Vanopizad }\end{array}$ & \begin{tabular}{|l|l|l|l} 
Final Heated \\
Soldd (drog) \\
\end{tabular} & $\%$ Solid & woty & Aliquot & $\begin{array}{lll}\text { Aliquot } \\
\text { ired Reside }\end{array}$ & 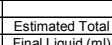 & \begin{tabular}{|l} 
Estimated Total \\
Dissolved Solids (G) \\
\end{tabular} & 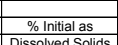 & \begin{tabular}{|l} 
Resin Mass \\
\end{tabular} & \\
\hline $\begin{array}{l}\text { Run Date } \\
126169 \\
1015299 \\
\end{array}$ & \begin{tabular}{|l} 
WJJCode \\
WJC-I-1-148 \\
WWC-I-168 \\
\end{tabular} & \begin{tabular}{|l}
$\mid$ Initi Resing (g) \\
0.402 \\
0.401
\end{tabular} & $\begin{array}{c}\text { Initi. Acid (g) } \\
9.980 \\
10.038\end{array}$ & $\begin{array}{l}\text { Init. Totat Mass (9) } \\
10.382 \\
10.349\end{array}$ & \begin{tabular}{|l} 
Final otal Mass $(\mathrm{g})$ \\
7.0410 \\
7.510
\end{tabular} & $\begin{array}{l}\frac{\text { Vaporized }}{32.2} \\
28.1 \\
28 .\end{array}$ & \begin{tabular}{|l} 
Solid (dry, g) \\
0 \\
\end{tabular} & $\frac{\text { Recovered }}{0.0}$ & & \begin{tabular}{|l|} 
Density $(9 \mathrm{mit}$ \\
1.176 \\
1.160
\end{tabular} & $\begin{array}{l}\frac{\text { Uned Resicue }}{0.1299} \\
0.1196\end{array}$ & 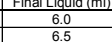 & \begin{tabular}{|c|} 
issolved Solids (g) \\
0.2590 \\
0.2582
\end{tabular} & $\begin{array}{l}\text { Dissolved Solli } \\
64.4 \\
64.4 \\
\end{array}$ & \begin{tabular}{|l|} 
Balance (\%) \\
64.4 \\
64.4 \\
\end{tabular} & $\begin{array}{l}\text { Noles } \\
\text { Cleas rut (Profiles in presentation) } \\
\text { Clean run except for dip during heatup }\end{array}$ \\
\hline 2114100 & WJC-1-1-130 & 0.400 & 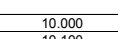 & $\frac{10.400}{100}$ & 7.400 & 28.8 & 0 & 0.0 & & 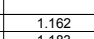 & 0.1105 & 6.4 & 0.2346 & 58.7 & 58.7 & Run with gas analysis r result, dip during heatup; gas sample brown \\
\hline & & & $\begin{array}{c}10.100 \\
\text { Dens }=1.15 \mathrm{~g} / \mathrm{ml} \\
\end{array}$ & & & & & & & & & & AVERAGE & 62.5 & 62.5 & Cas sample capture attempt \#1 \\
\hline & & & & & & & & & & & & & & & & \\
\hline H2O (Blank) Ru & & & & & & \% Material & \begin{tabular}{|l|} 
Final Heated \\
\end{tabular} & $\%$ solid & & & & & & & esin 1 & \\
\hline $\begin{array}{l}\text { Run Date } \\
118999 \\
114100 \\
\end{array}$ & 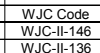 & \begin{tabular}{|l}
$\frac{\text { Initi Resin (g) }}{0.406}$ \\
0.400
\end{tabular} & $\frac{\text { Init. H2O }}{10.099}$ & \begin{tabular}{|l} 
Init. Total Mass (g) \\
10.45 \\
10440
\end{tabular} & \begin{tabular}{|l|} 
Final Total Mass (g) \\
8.728 \\
8.74 \\
\end{tabular} & $\begin{array}{l}\frac{V^{\text {Vaporized }}}{16.2} \\
16.0 \\
10.0\end{array}$ & 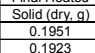 & $\begin{array}{l}\text { Recovered } \\
4.1 \\
4.1 \\
4.1\end{array}$ & $\begin{array}{ll}\text { Aliquot Vol. (ml) } \\
3\end{array}$ & $\begin{array}{l}\frac{\text { Density (g/mil }}{1.54} \\
1.5099 \\
\end{array}$ & 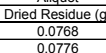 & 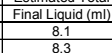 & $\frac{\text { Dissolved Solids (g) }}{0.2072}$ & \begin{tabular}{|l} 
Dissolved Solids \\
$\frac{51.0}{53.4}$ \\
5.4
\end{tabular} & \begin{tabular}{|l} 
Balance (\%) \\
9.9 .1 \\
101.5
\end{tabular} & 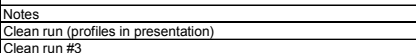 \\
\hline $11 / 4 / 99$ & WJC-II-162 & 0.400 & 10.060 & 10.460 & 8.899 & 14.9 & 0.2047 & 51.2 & 3 & 1.052 & 0.0701 & 8.5 & 0.1977 & 49.4 & 100.6 & Big dip during hold time \\
\hline Allruns performet & $\frac{1}{d}$ Using Superhis & .644 Batch nuा & 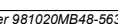 & & & & & & & & & & & & & \\
\hline & & & & & & & & & & & & & & & & \\
\hline Mass Balance Su & imary & & & & & & & & & & & & & & & \\
\hline & Initial Resin(g) & Final Resin(o) & Dissolved Solids S & $\begin{array}{l}\text { Mass Balance } \\
\text { Closure }\end{array}$ & \begin{tabular}{|l|l|} 
\% Initial Resin & \\
as Dissolyed Solils \\
\end{tabular} & & & & & & & & & & & \\
\hline $\begin{array}{ll}\text { Acid Run \#1 } \\
\text { Adid Run } \# 2\end{array}$ & $\frac{1}{0.402}$ & $\frac{0}{0}$ & $\frac{0.2590}{0.250}$ & $\frac{654.4}{64.4}$ & 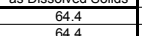 & & & & & & & & & & & \\
\hline Water Run \#1 & 0.406 & 0.1951 & 0.2072 & 99.1 & 51.0 & & & & & & & & & & & \\
\hline $\begin{array}{l}\text { Water Run \#2 } \\
\text { Wet }\end{array}$ & 0.400 & 0.1923 & 0.2136 & 101.5 & 53.4 & & & & & & & & & & & \\
\hline
\end{tabular}

Guide to DSC and TGA Data

- Fresh resin is "as-received" resin that was placed directly into the DSC or TGA analytical instrument

- Samples labeled by run number (WJC-XX-XXX) are DSC or TGA of dried dissolved solids obtained by drying the liquid phase remaining after the RSST run was completed.

- Samples labeled by run number followed by "SOLID" are DSC or TGA of dried residual solids remaining from the water "blank" experiments after the RSST run was complete. These solids were dried after removal of the liquid phase. 
WSRC-TR-2000-00411

SRT-RPP-2000-00027

$\underline{\text { DSC and TGA Data }}$
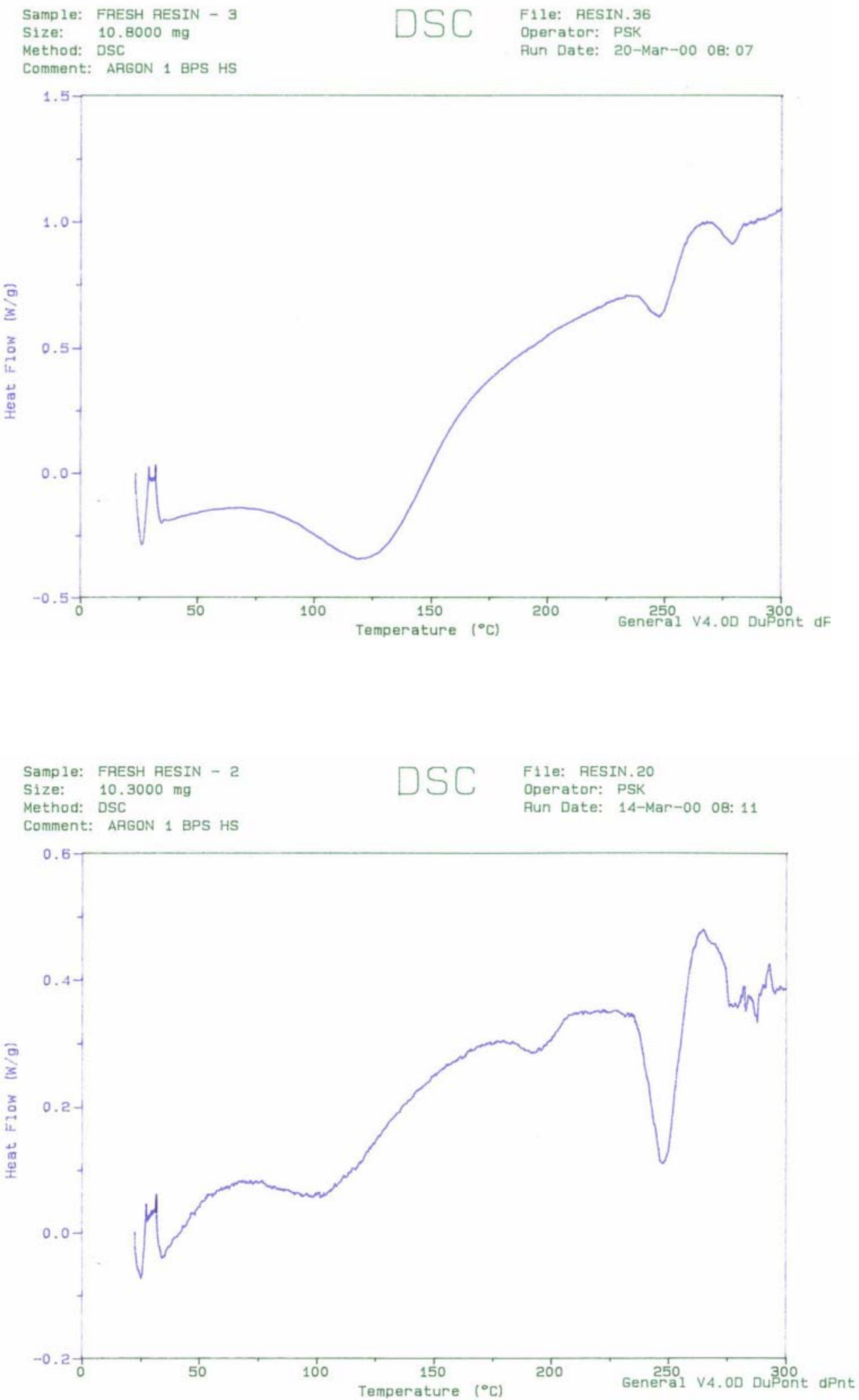
WSRC-TR-2000-00411

SRT-RPP-2000-00027
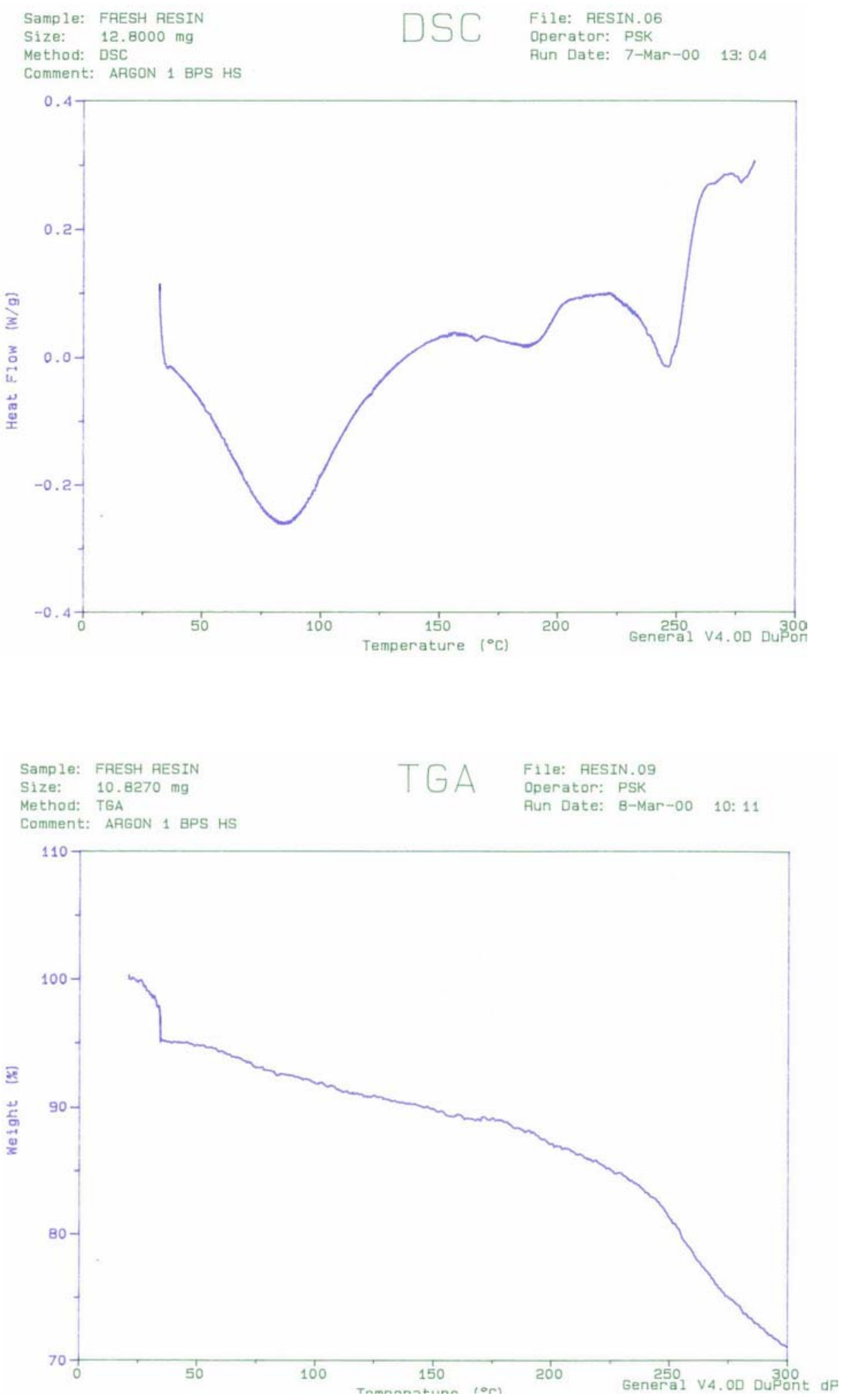
WSRC-TR-2000-00411

SRT-RPP-2000-00027
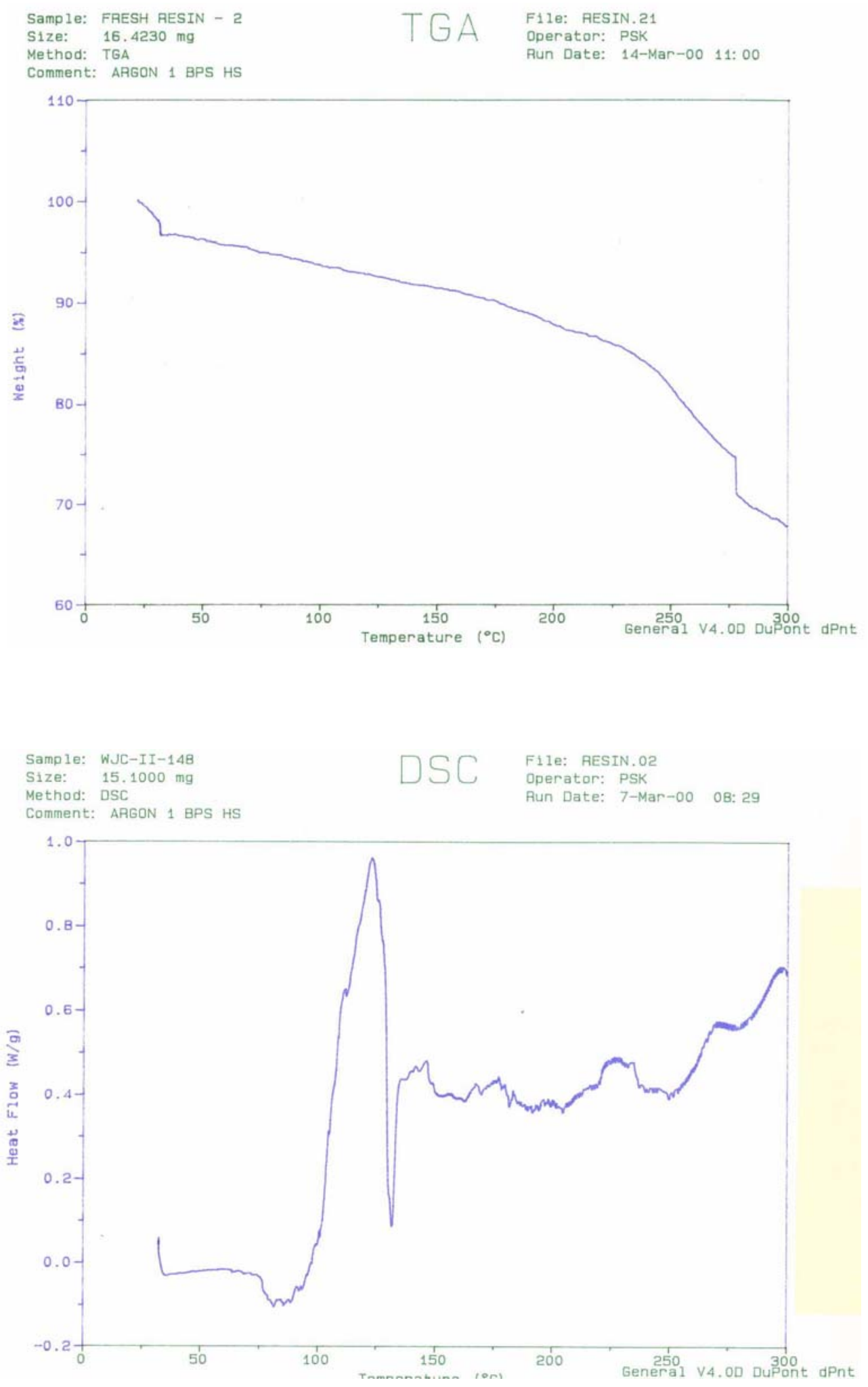
WSRC-TR-2000-00411

SRT-RPP-2000-00027
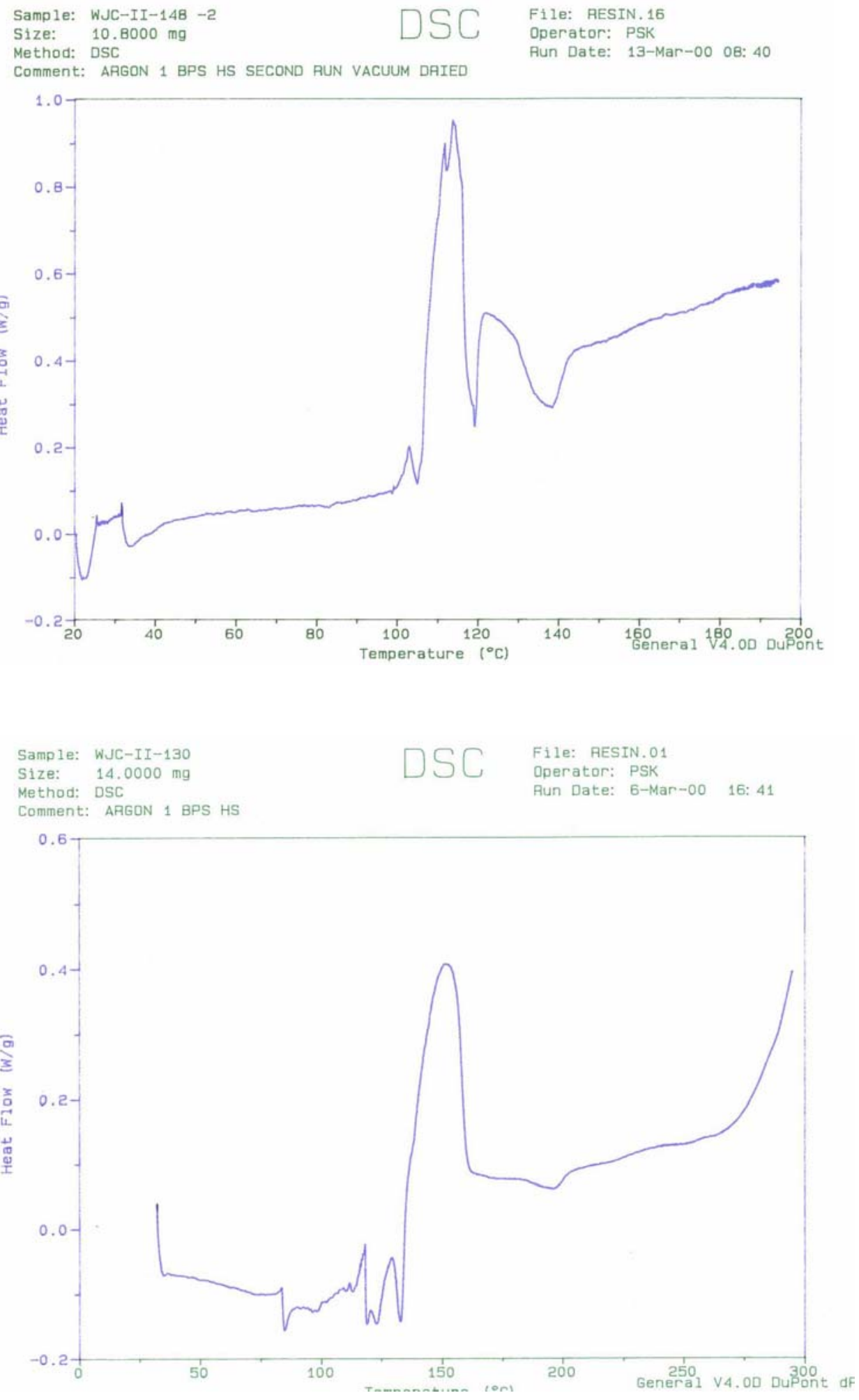
WSRC-TR-2000-00411

SRT-RPP-2000-00027
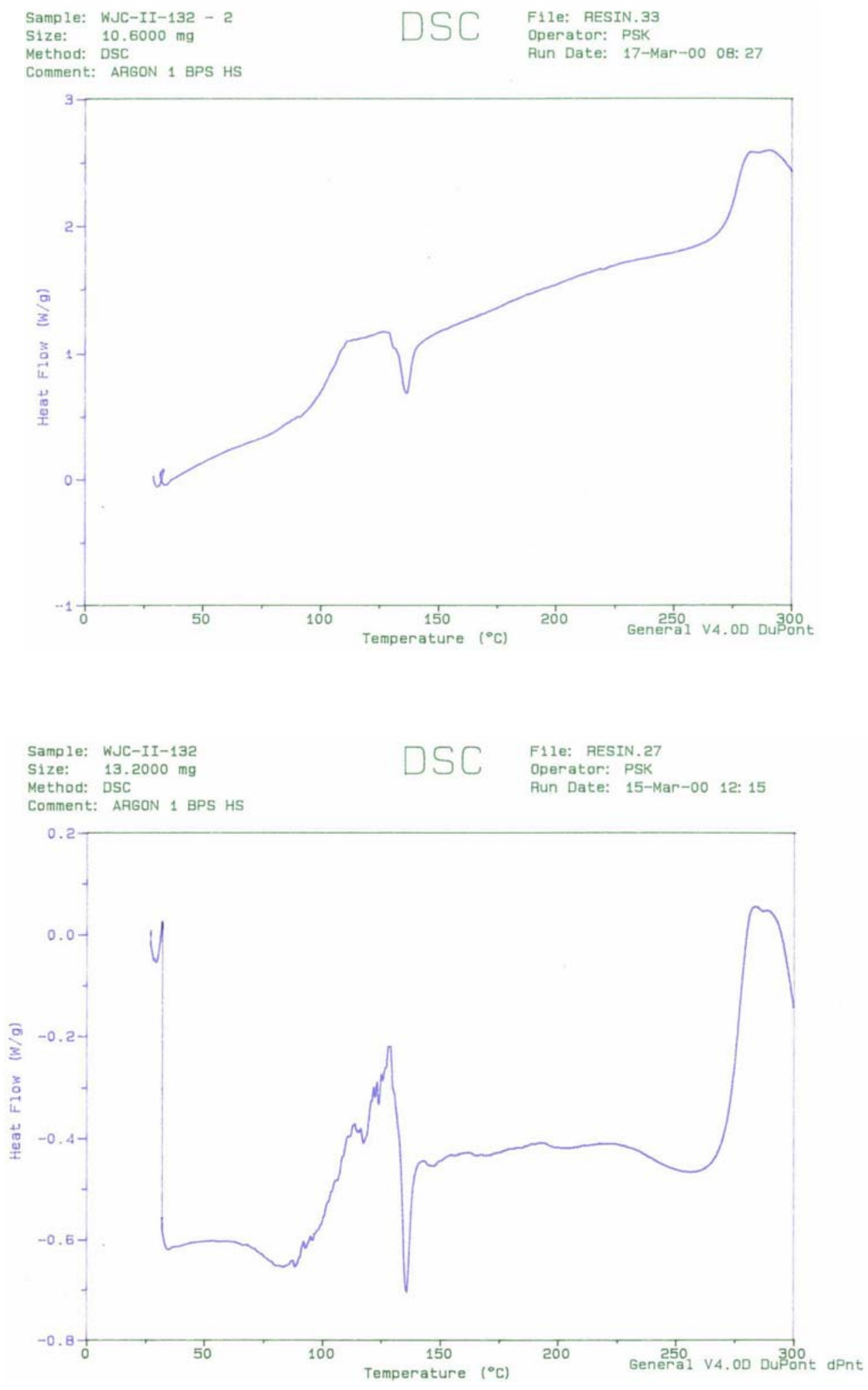
WSRC-TR-2000-00411

SRT-RPP-2000-00027
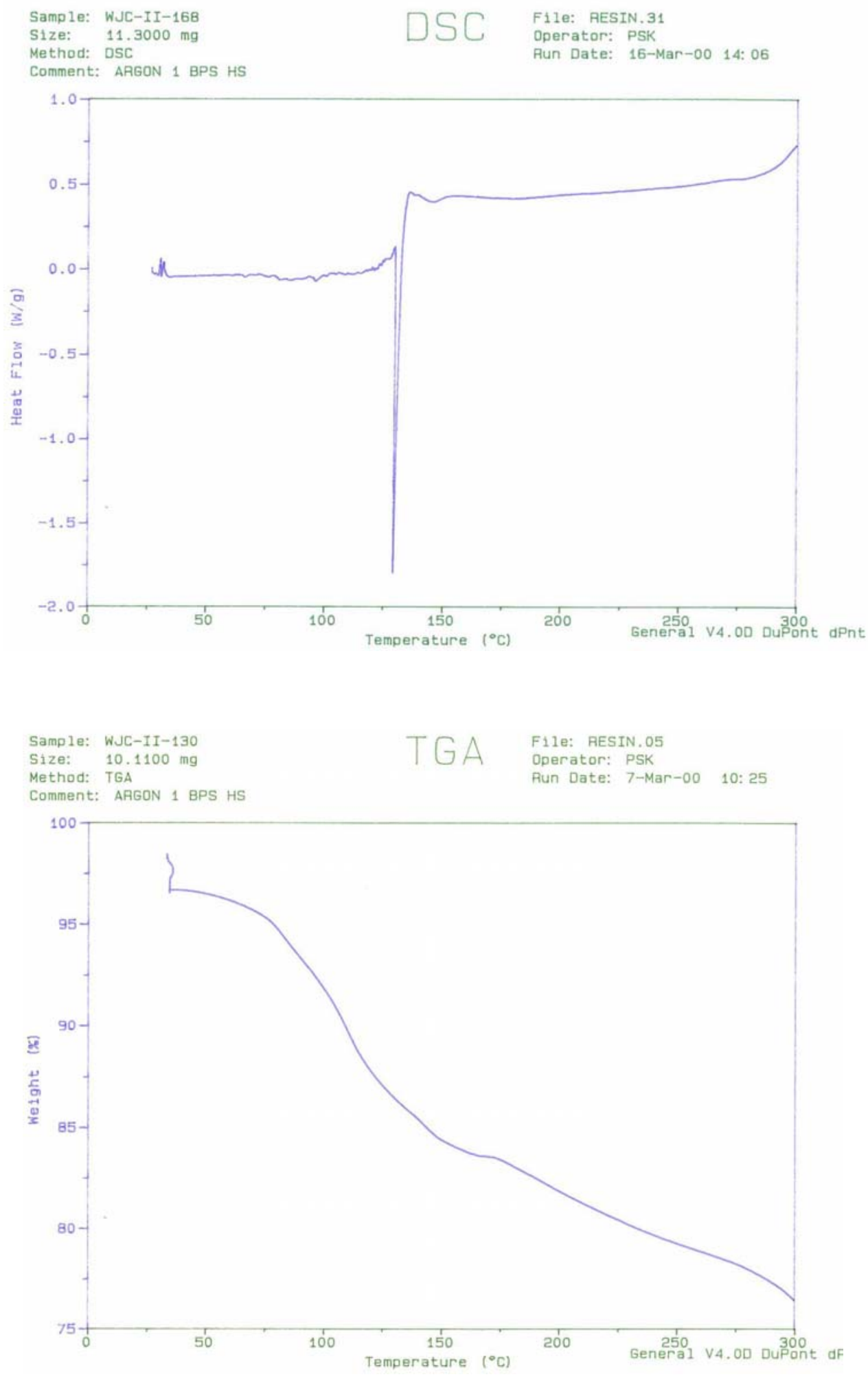
WSRC-TR-2000-00411

SRT-RPP-2000-00027
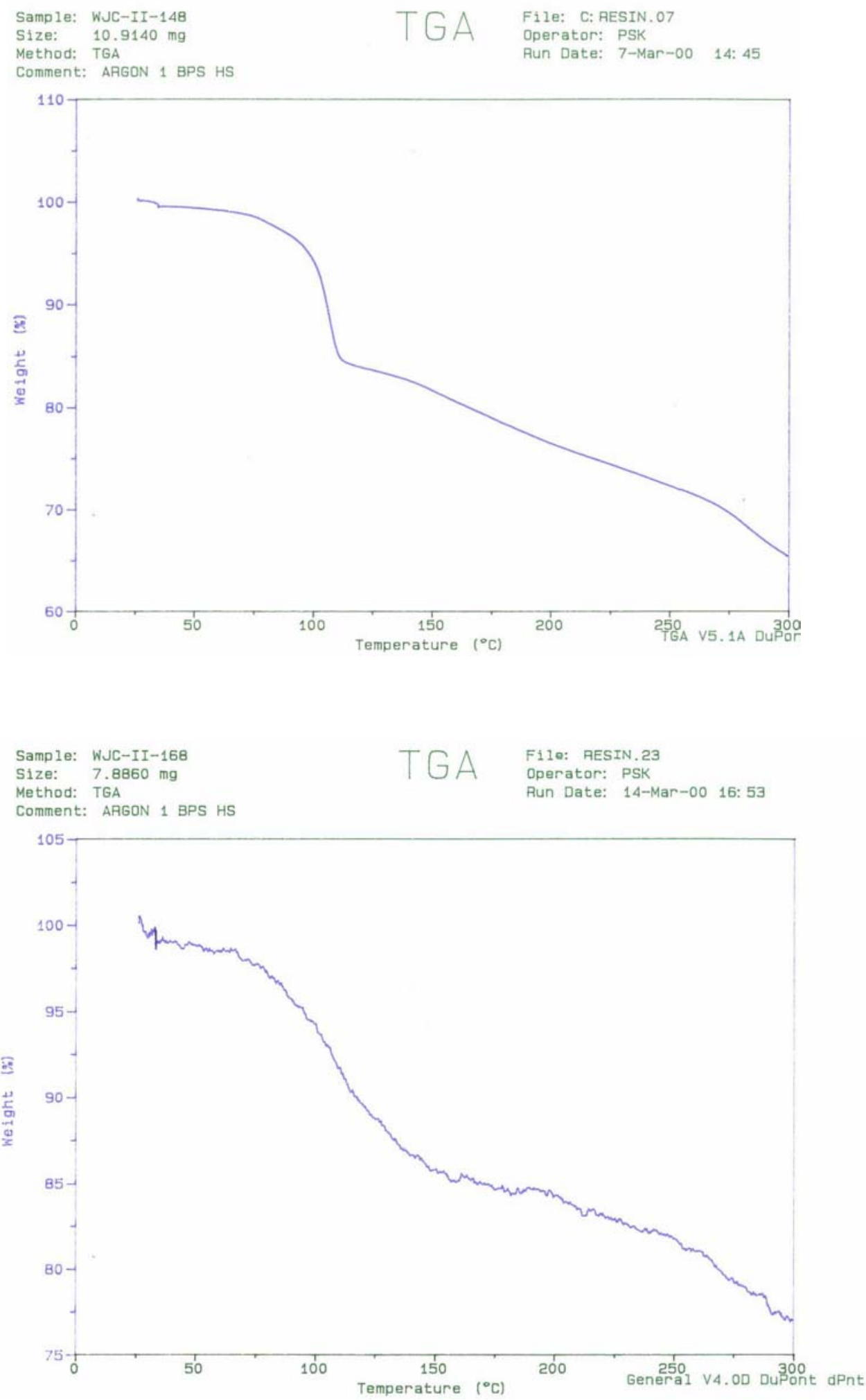
WSRC-TR-2000-00411

SRT-RPP-2000-00027
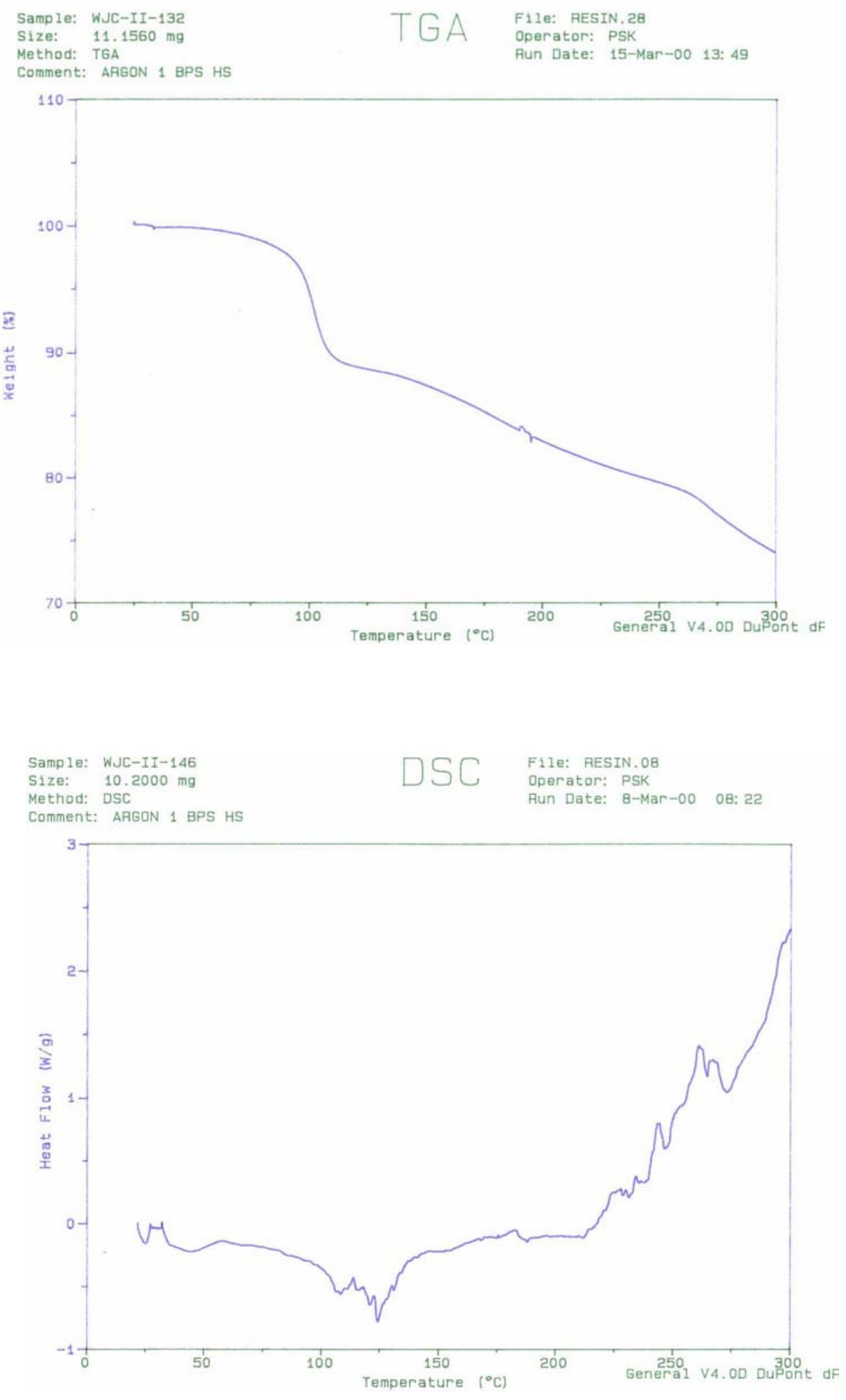
WSRC-TR-2000-00411

SRT-RPP-2000-00027
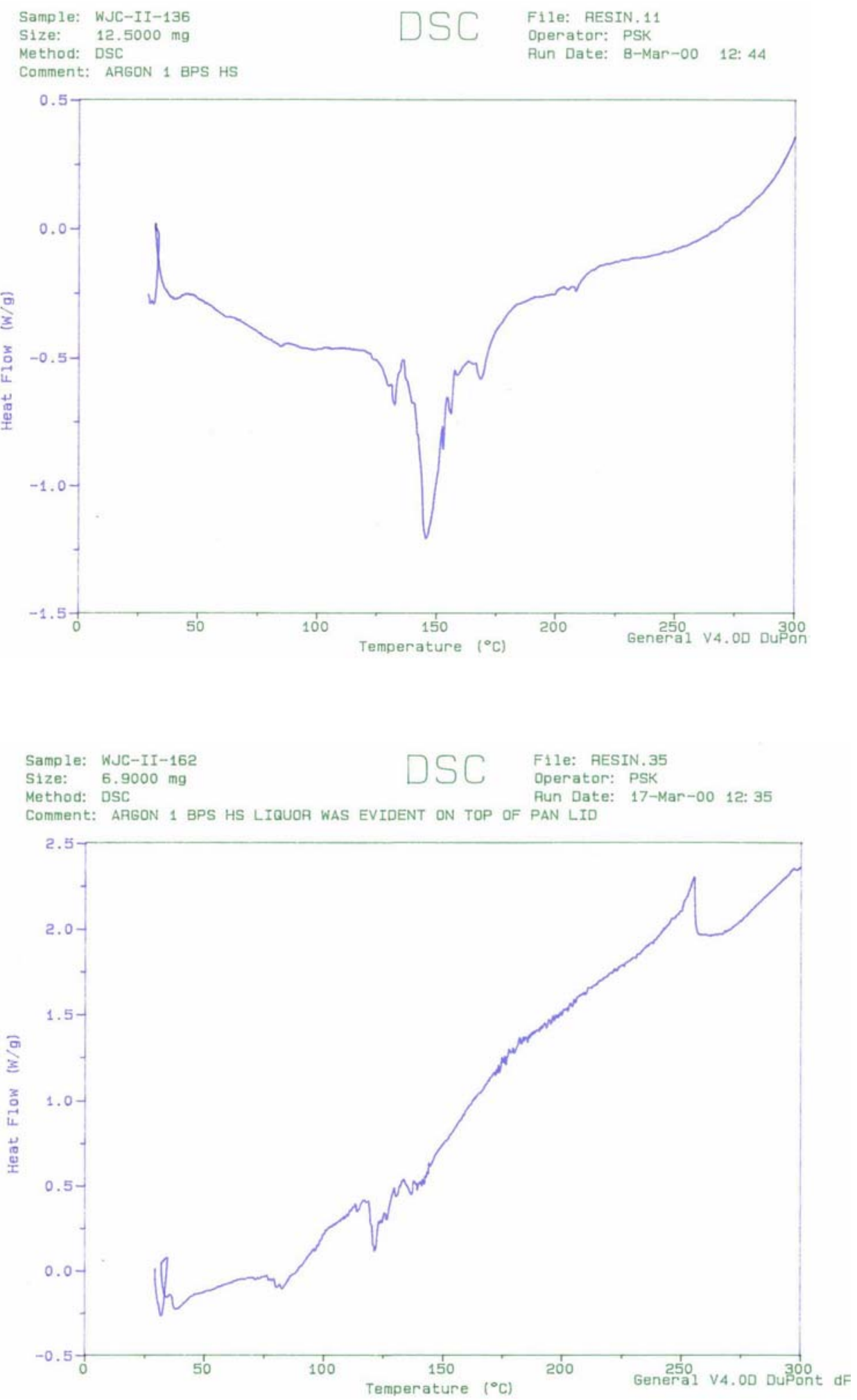
WSRC-TR-2000-00411

SRT-RPP-2000-00027
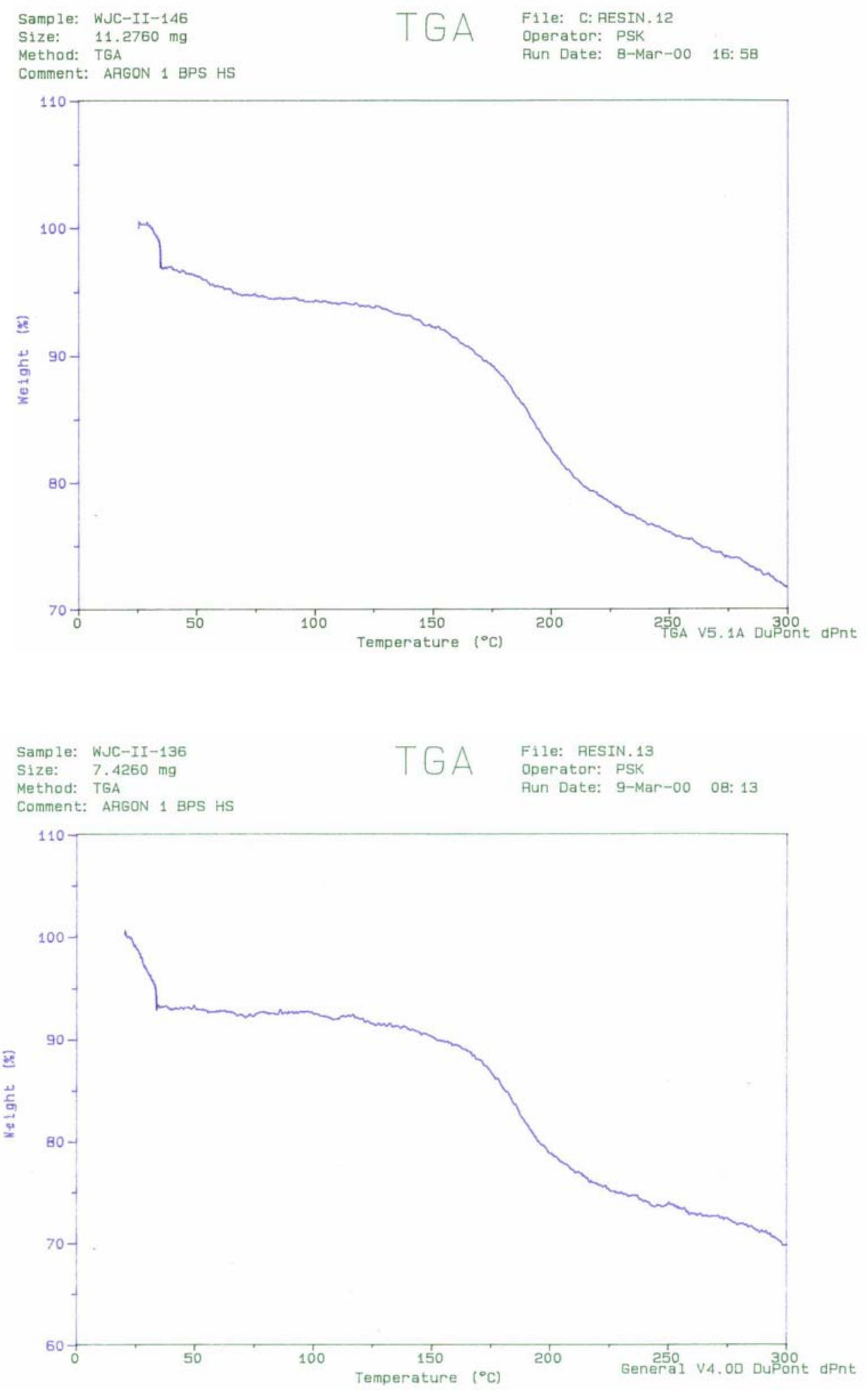
WSRC-TR-2000-00411

SRT-RPP-2000-00027
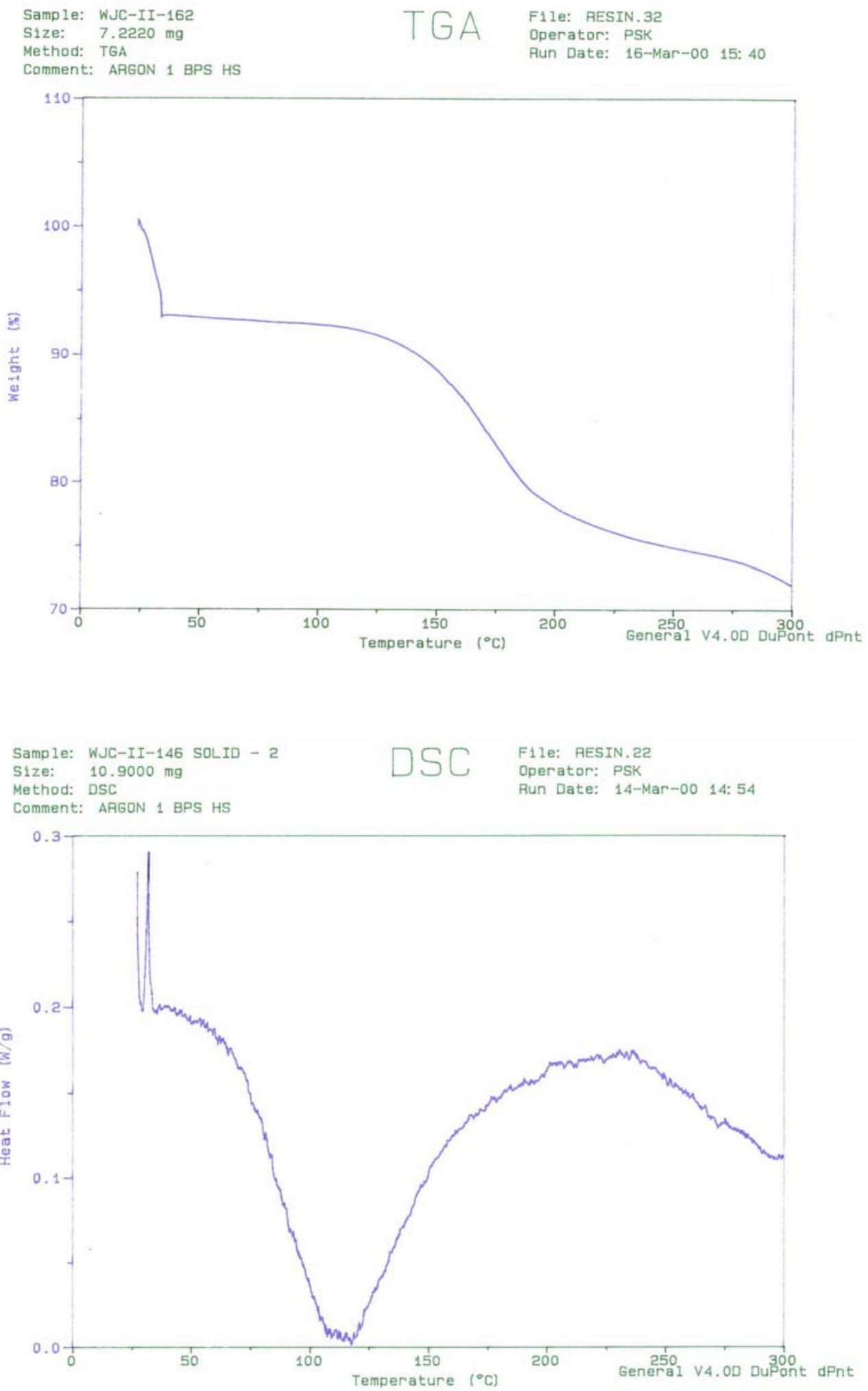
WSRC-TR-2000-00411

SRT-RPP-2000-00027
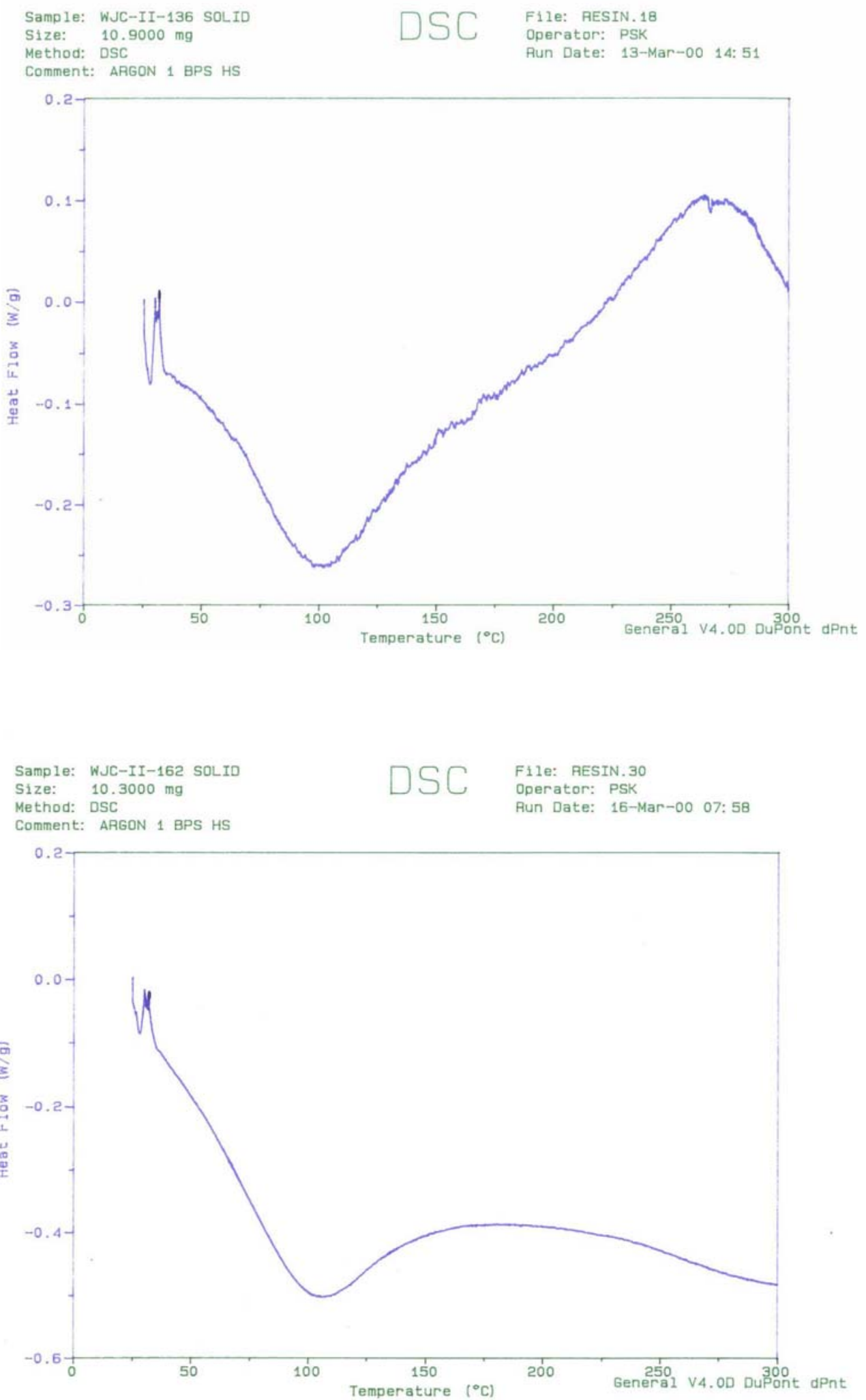
WSRC-TR-2000-00411

SRT-RPP-2000-00027

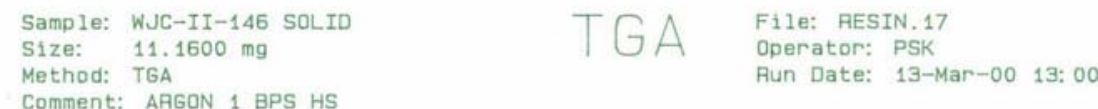

Comment: ARGON 1 BPS HS
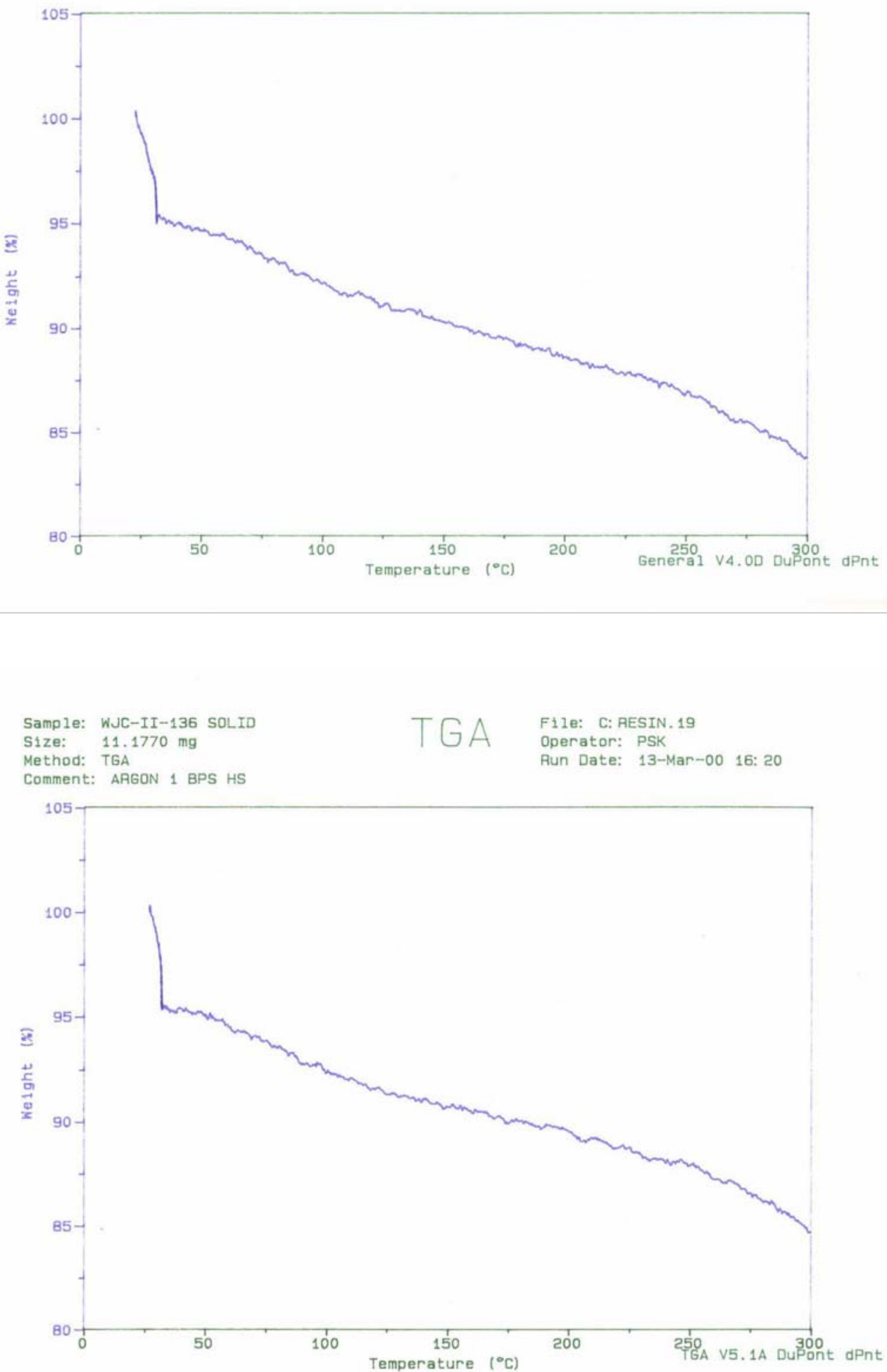
WSRC-TR-2000-00411

SRT-RPP-2000-00027

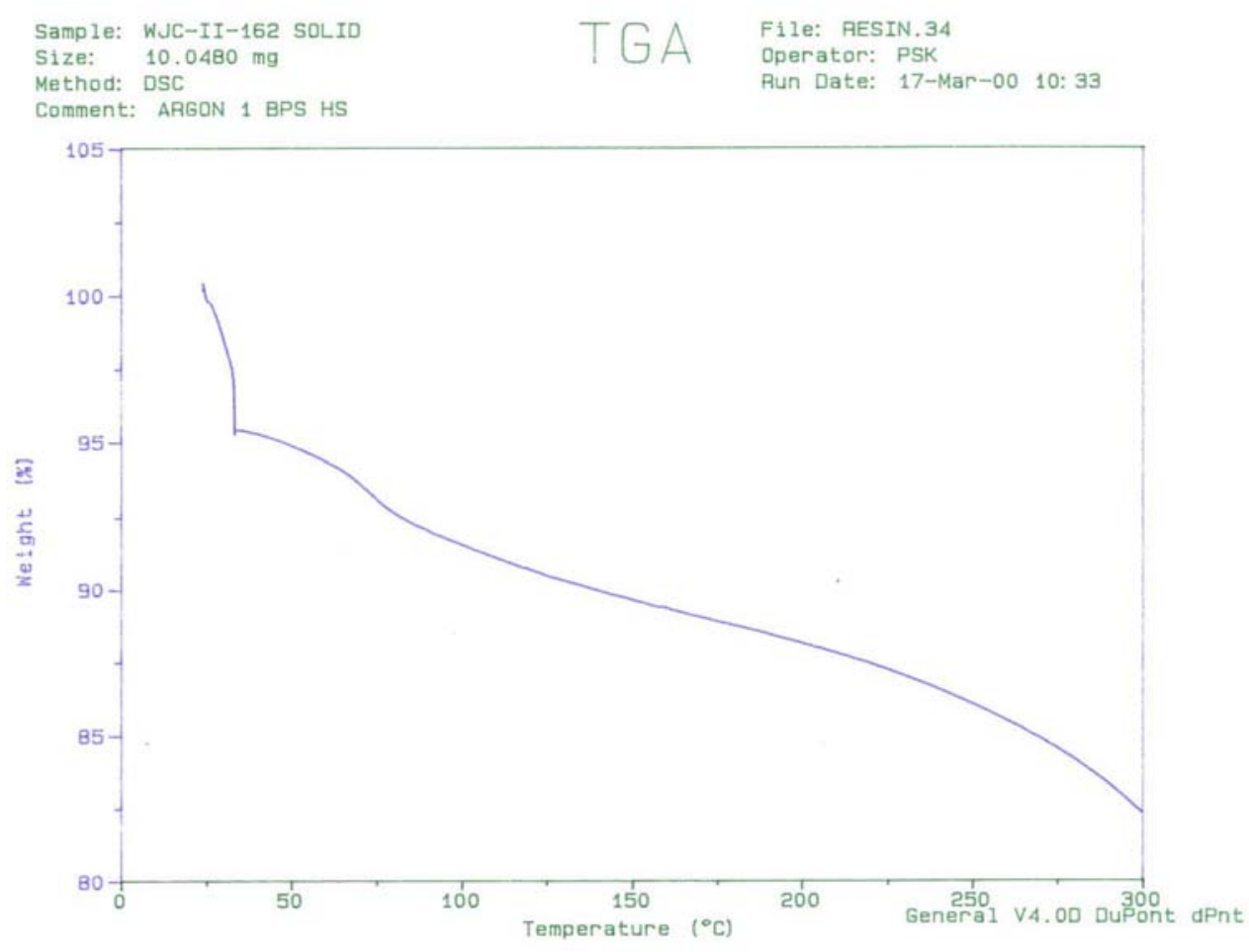




\section{Appendix B. Identified Compounds in Acid-Run Liquid Phase}

\begin{tabular}{|l|l|l|}
\hline \multirow{3}{*}{ Sample \# } & Concentration $(\mathrm{mg} / \mathrm{L})$ \\
\cline { 2 - 3 } & 3,4 -dimethyl-2,5-furandione & 3-ethyl-4-methyl-2,5-furandione \\
\hline 1 & 0.28 & 0.36 \\
\hline 2 & 0.28 & 0.25 \\
\hline 3 & 0.28 & 0.32 \\
\hline 4 & 0.37 & 0.40 \\
\hline
\end{tabular}

Table B-1. Concentrations of organic compounds identified by GC-MS in the acid-run liquid phase (SuperLig ${ }^{\mathrm{TM}} 644 / 5 \mathrm{M} \mathrm{HNO} 3$ after 24 hours at $90-96^{\circ} \mathrm{C}$ ). Detection limit was $0.25 \mathrm{mg} / \mathrm{L}$.

\begin{tabular}{|l|l|l|}
\hline \multirow{2}{*}{ Compound } & Concentration $(\mu \mathrm{g} / \mathrm{L})$ & \\
\cline { 2 - 3 } & Acid-Run & $\mathrm{HNO}_{3}$ Only (Blank) Run \\
\hline Toluene & 110 & 36 \\
\hline Unknown Silicon-based & 35 & ------ \\
\hline 3-methyl-hexane & 23 & 12 \\
\hline 4,4-dimethyl-2-pentanone & 12 & ------ \\
\hline 1-butene & ------ & 7.7 \\
\hline 2,4,4-trimethyl-1-pentene & ------ & 78 \\
\hline 2,4,4-trimethyl-2-pentene & ------ & 14 \\
\hline Methylcyclohexane & ------ & 8.3 \\
\hline Pentanal & ----- & 4.5 \\
\hline Trace hydrocarbons $(\sim 10)$ & $<10$ (each) & ------ \\
\hline
\end{tabular}

Table B-2. Concentrations of organic compounds identified by GC-MS in the acid-run gas phase (SuperLig ${ }^{\mathrm{TM}} 644 / 5 \mathrm{M} \mathrm{HNO3}$ after 24 hours at $90-96^{\circ} \mathrm{C}$ ) 


\section{Appendix C. X-ray Diffraction Data for SuperLig ${ }^{\mathrm{TM}} 644$ Ion Exchange Resin}

Data is courtesy of Neguib Hassan, Actinide Technology Section (ATS). The first two spectra show potassium bicarbonate as the dominant inorganic salt present in the "as-received" resin. The final two spectra show that the potassium bicarbonate was removed by a pre-conditioning process where the resin was: 1) allowed to soak in $1 \mathrm{M} \mathrm{NaOH}$ solution for 2 hours, 2) sluiced into an ion exchange column, 3) rinsed with 2 total apparatus volumes of de-ionized water, 4) eluted using 10 total apparatus volumes of $0.5 \mathrm{M} \mathrm{HNO}_{3}$ solution, 5) rinsed with 2 total apparatus volumes of de-ionized water, 6) regenerated using 2 total apparatus volumes of $0.25 \mathrm{M} \mathrm{NaOH}$ solution, 7) rinsed with 2 total apparatus volumes of de-ionized water, 8) filtered, and 9) vacuum oven-dried at $50 \pm 5^{\circ} \mathrm{C}$. 
WSRC-TR-2000-00411

SRT-RPP-2000-00027

"As-received" Resin XRD Data
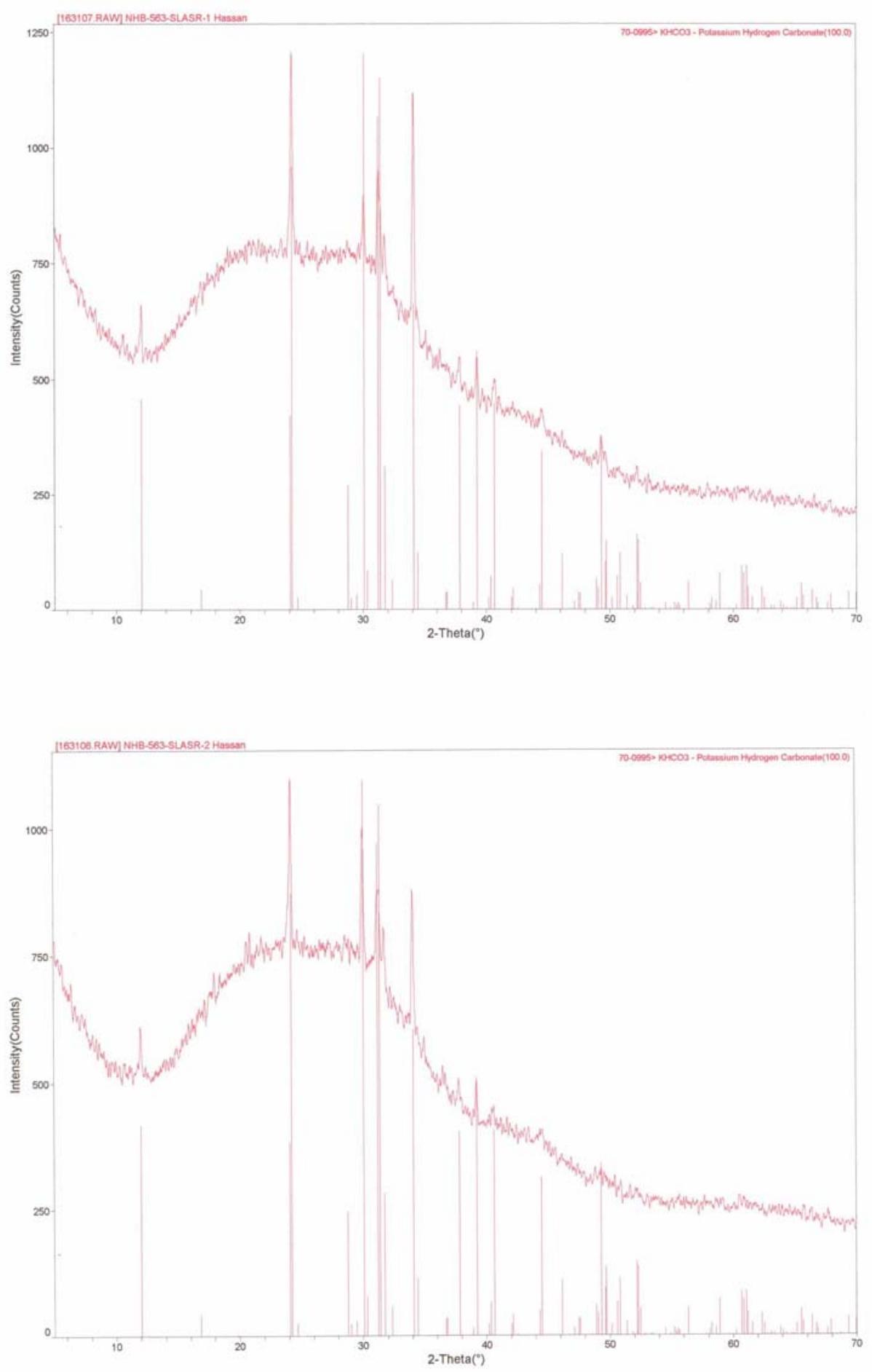
WSRC-TR-2000-00411

SRT-RPP-2000-00027

$\underline{\text { Pre-conditioned Resin XRD Data }}$

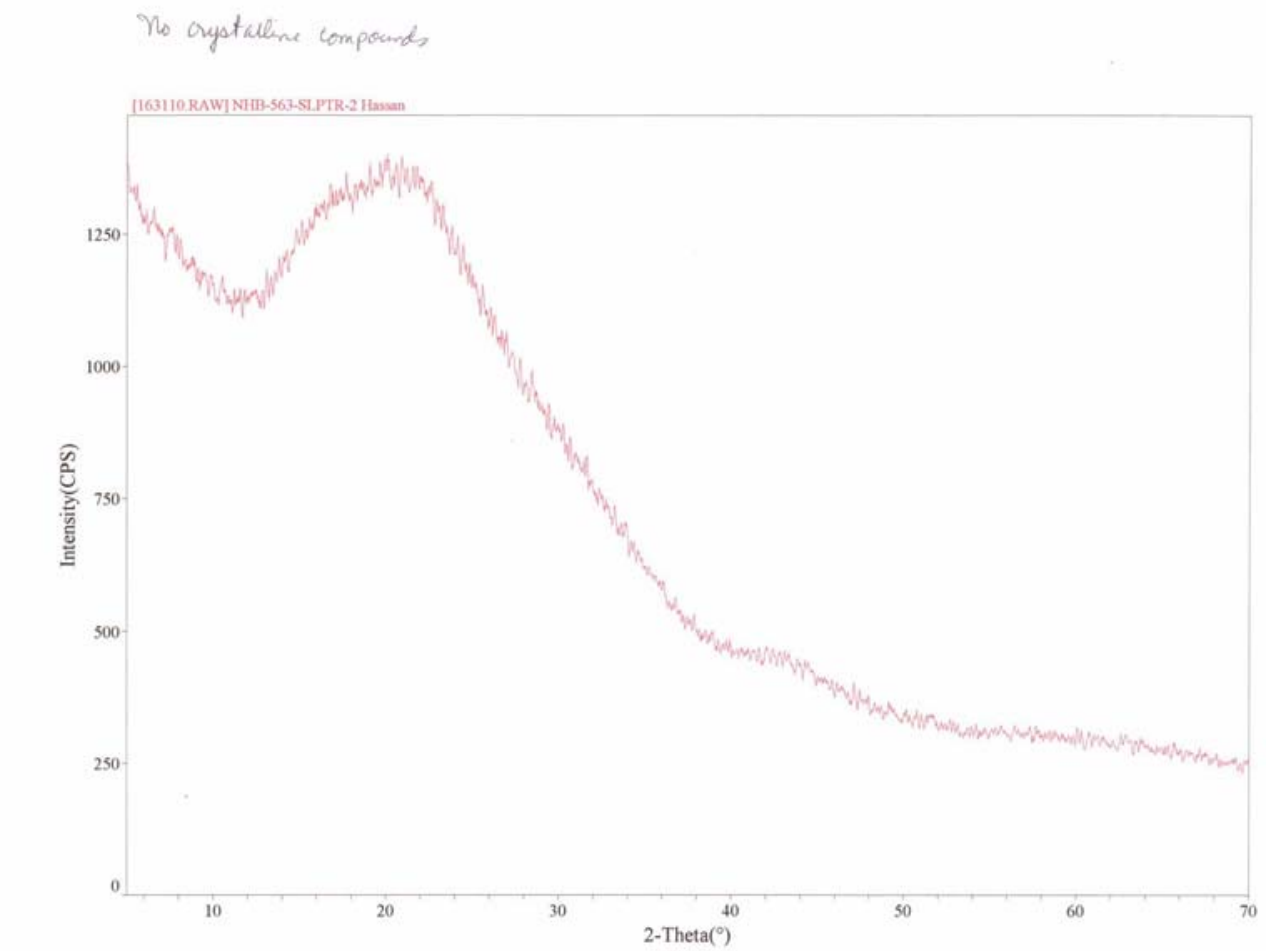

Savannah River Site

No erystallene compounds

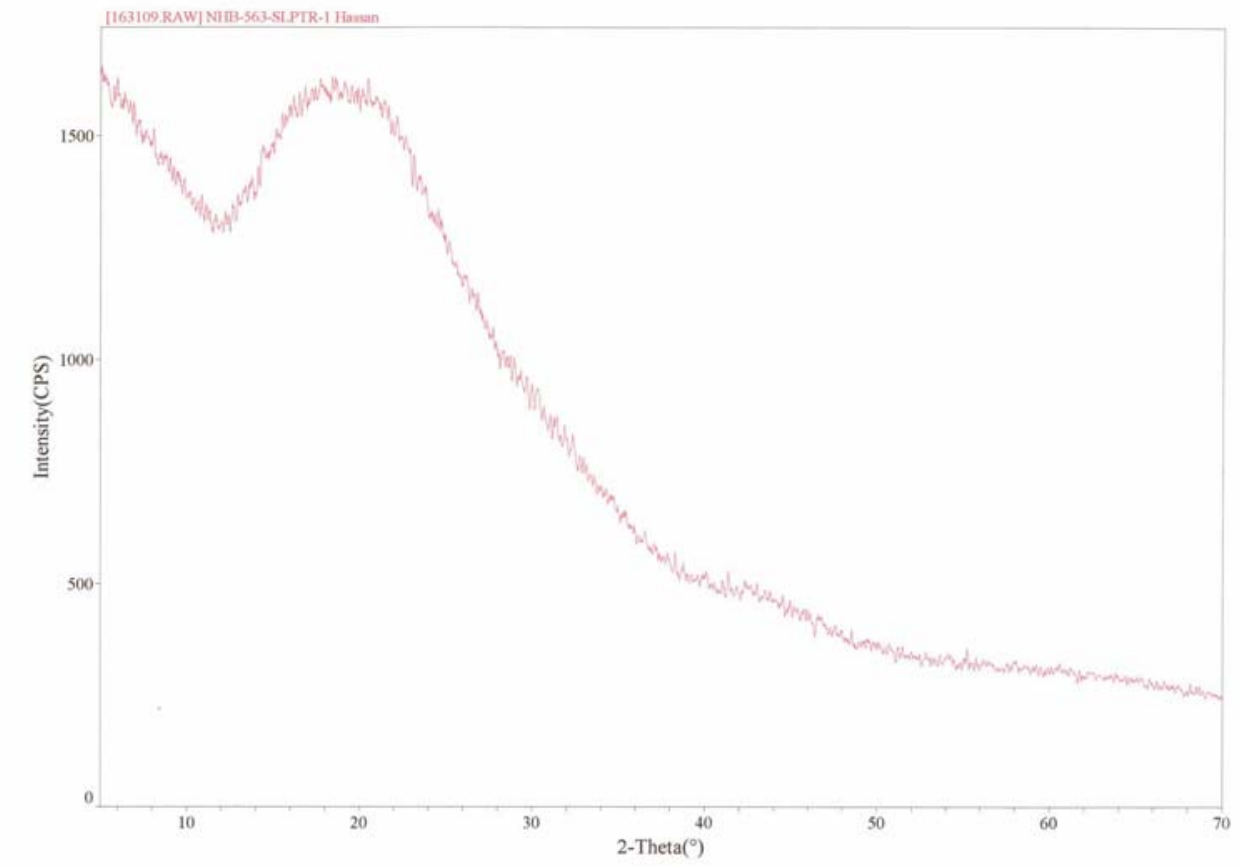

Savannah River Site 